\title{
Artigo Original / Original Paper \\ Clado Mimosoide (Leguminosae e Caesalpinioideae) no Parque Estadual da Serra dos Montes Altos, Bahia, Brasil
}

\author{
Mimosoid clade (Leguminosae-Caesalpinioideae) in the Serra dos Montes Altos State Park, \\ Bahia, Brazil
}

José Milton Silva Freire Júnior ${ }^{1,2} \&$ Juliana Santos Silva ${ }^{1,3,4}$

\begin{abstract}
Resumo
O clado Mimosoide pertence à subfamília Caesalpinioideae, segundo a nova classificação das Leguminosae e inclui espécies tradicionalmente pertencentes à Mimosoideae. O presente trabalho consiste no estudo taxonômico das espécies do clado Mimosoide presentes no Parque Estadual da Serra dos Montes Altos, localizado na porção centro-sul da Bahia. Foram realizadas coletas do material botânico no período de 12 meses (maio/2015 a abril/2016) através de caminhadas aleatórias mensais. Além das espécies coletadas em campo, foram analisados também materiais dos herbários HUEFS, HUNEB - Coleção Caetité e HUESBVC. Foram registradas 16 espécies distribuídas em oito gêneros. Os gêneros mais representativos foram Mimosa com sete espécies e Calliandra com três. Notou-se que $62 \%$ das espécies ocorrem preferencialmente em vegetação de Cerrado. Características como número de folíolos, forma e localização de nectários, tipo de inflorescência, morfologia dos frutos e sementes foram essenciais para identificação dos táxons. São apresentadas chave de identificação, descrições, caracteres diagnósticos, distribuição geográfica e fotografias das espécies estudadas. Palavras-chave: Fabaceae, florística, Nordeste do Brasil, Semiárido, taxonomia vegetal.
\end{abstract}

\begin{abstract}
According to the new classification of the Leguminosae, the Mimosoid clade belongs to the subfamily Caesalpinioideae, and includes species traditionally assigned to Mimosoideae. The present work consists of a taxonomic study of species of the Mimosoid clade encountered in Serra dos Montes Altos State Park, located in central-southern Bahia State, Brazil. Botanical samples were collected over a 12 month period (May/2015 to April/2016) during monthly random walks through the area. In addition to the plants collected in the field, specimens from the HUEFS, HUESBVC and HUNEB-Collection Caetité herbaria were also analyzed. A total of 16 species distributed in eight genera were sampled. The most representative genera were Mimosa, with seven species, and Calliandra with three; $62 \%$ of the species occurred primarily in Cerrado vegetation. Characteristics such as number of leaflets, shape and location of nectary structures, type of inflorescence, fruit morphology and seeds were essential for the identification of taxa. A key to the identifications of taxa is provided, such as descriptions, diagnostic characters, photographs of the species studied, and their geographic distributions. Key words: Fabaceae, floristics, Northeastern Brazil, Semiarid, plant taxonomy.
\end{abstract}

\section{Introdução}

Leguminosae Juss. é a terceira maior família de Angiospermas, com aproximadamente 760 gêneros e mais de 19.500 espécies, perde em número de espécies apenas para Asteraceae e Orchidaceae (LPWG 2017). Apresenta distribuição cosmopolita, com maior riqueza e endemismos na região neotropical (Lavin et al. 2004; Lewis et al.
2005). É morfologicamente diversificada, sendo considerado um dos exemplos mais espetaculares de diversificação evolutiva nas plantas (LPWG 2017). Apesar disso, pode ser reconhecida por apresentar folhas compostas, alternas, com pulvino, pétala adaxial diferenciada, ovário monocarpelar e frutos geralmente do tipo legume (Lewis et al. 2005).

\footnotetext{
${ }^{1}$ Universidade do Estado da Bahia, Depto. Educação, Prog. Pós-graduação em Biodiversidade Vegetal, R. do Gangorra 503, Alves de Souza, 48608-240, Paulo Afonso, BA, Brasil.

${ }^{2}$ ORCID: <https://orcid.org/0000-0003-0804-2435>

3 ORCID: <https://orcid.org/0000-0003-0134-3438>

${ }^{4}$ Autor para correspondência: jussilva@uneb.br
} 
Baseada em análises filogenéticas mais abrangentes que incluíram cerca de $20 \%$ das espécies conhecidas de Leguminosae, uma nova classificação intrafamiliar com seis subfamílias foi recentemente proposta (LPWG 2017). Nessa configuração, a tradicional subfamília Mimosoideae passou a ser reconhecida como uma linhagem interna da subfamília Caesalpinioideae.

O clado Mimosoide compreende 82 gêneros com cerca de 3.300 espécies distribuídas principalmente em regiões tropicais, subtropicais e temperadas quentes, compreendendo a América tropical, África e Australásia como seus atuais centros de endemismo (Lewis et al. 2005; LPWG 2017). O Brasil engloba 637 espécies reunidas em 28 gêneros (BFG 2018).

Seus representantes compartilham folhas bipinadas, com foliólulos frequentemente numerosos, flores actinomorfas, inconspícuas (sendo os estames a parte mais visível da flor), e sépalas e pétalas geralmente unidas na base, reunidas em espiga ou glomérulo e sementes com pleurograma visível em forma de «U» (Lewis et al. 2005; LPWG 2017).

Além de sua importância ecológica natural na manutenção do equilíbrio dos ecossistemas, os representantes do clado Mimosoide possuem grande relevância econômica tanto na alimentação humana e animal quanto na indústria madeireira, tinturaria, apicultura, paisagismo e cosméticos (Lewis et al. 2005).

Apesar de diferentes trabalhos terem demonstrado a alta diversidade do clado Mimosoide no nordeste do Brasil, com aproximadamente 22 gêneros e 95 espécies (e.g., Ducke 1953; Lewis 1987; Moura \& Barbosa 1995; Cardoso \& Queiroz 2007; Córdula et al. 2008; Queiroz 2009; Dourado et al. 2013), ainda existem muitas regiões que foram pouco coletadas e sua flora permanece pouco conhecida, como é o caso do Parque Estadual da Serra dos Montes Altos (PESMA).

O PESMA é uma unidade de conservação situada na Serra dos Montes Altos, entre o Rio São Francisco e o braço principal da Serra do Espinhaço, abrangendo os municípios de Palmas de Monte Alto, Sebastião Laranjeiras, Guanambi, Candiba, Pindaí e Urandi (Silva 2012). Apresenta uma grande diversidade de belezas paisagísticas, inclusive com vários cursos d'água, em um mosaico de fisionomias, como Cerrado, Caatinga, Campos rupestres e Florestas ribeirinhas, o que tem gerado um fluxo de turismo local sem algum planejamento (Soares Filho 2012).

A flora do PESMA tem sido pouco estudada, até o momento, nenhum trabalho sobre a taxonomia de grupos de plantas foi realizado, apenas listagens florísticas preliminares foram elaboradas registrando a ocorrência de 98 espécies pertencentes a 66 gêneros e 33 famílias (Soares Filho 2012; Soares Filho et al. 2012). Segundo estes trabalhos, as famílias com maior riqueza de espécies na região são Leguminosae com 31 espécies seguida de Myrtaceae ( 8 spp.) e Annonaceae (5 spp). Dentre as espécies registradas de Leguminosae, 10 pertencem ao clado Mimosoide.

Neste contexto, o objetivo deste trabalho foi realizar o estudo taxonômico das espécies do clado Mimosoide ocorrentes no PESMA, de forma a contribuir para o conhecimento da flora desta unidade de conservação, bem como fornecer subsídios para projetos de Recuperação de Áreas Degradadas da região, provendo descrições morfológicas, chave de identificação, ilustrações e imagens, comentários sobre a distribuição geográfica e ambiente preferencial das espécies.

\section{Material e Métodos}

Área de estudo

O PESMA está localizado na região CentroSul do estado da Bahia, entre as latitudes $14^{\circ} 15^{\prime}$, a $14^{\circ} 40^{\prime}$ S e longitudes $42^{\circ} 45^{\prime}$ a $43^{\circ} 10^{\prime} \mathrm{W}$ (Fig. 1). Ocupa uma área de 18.491 ha nos topos da Serra dos Montes Altos ou Serra de Monte Alto (SMA), com altitude média de $900 \mathrm{~m}$, embora alguns picos ultrapassem os $1.000 \mathrm{~m}$ (Silva 2012). O clima da região é caracterizado como semiárido, com índice pluviométrico anual médio de 694 $\mathrm{mm}$. O período mais chuvoso é de novembro a março, que compreende a primavera e o verão. A temperatura anual média é de $22,6^{\circ} \mathrm{C}$ (Rodrigues 2012). Porém, a serra também sofre influência dos rios e da altitude, por isso apresenta formações vegetacionais diversificadas, como florestas (secas e ripárias), Caatinga, Cerrado, áreas rupícolas e brejosas (Fig. 2) (Silva 2012).

\section{Estudo taxonômico}

Representantes do clado Mimosoide foram coletados mensalmente ao longo de trilhas e estradas, no período de maio/2015 a abril/2016, de forma a abranger os diferentes 


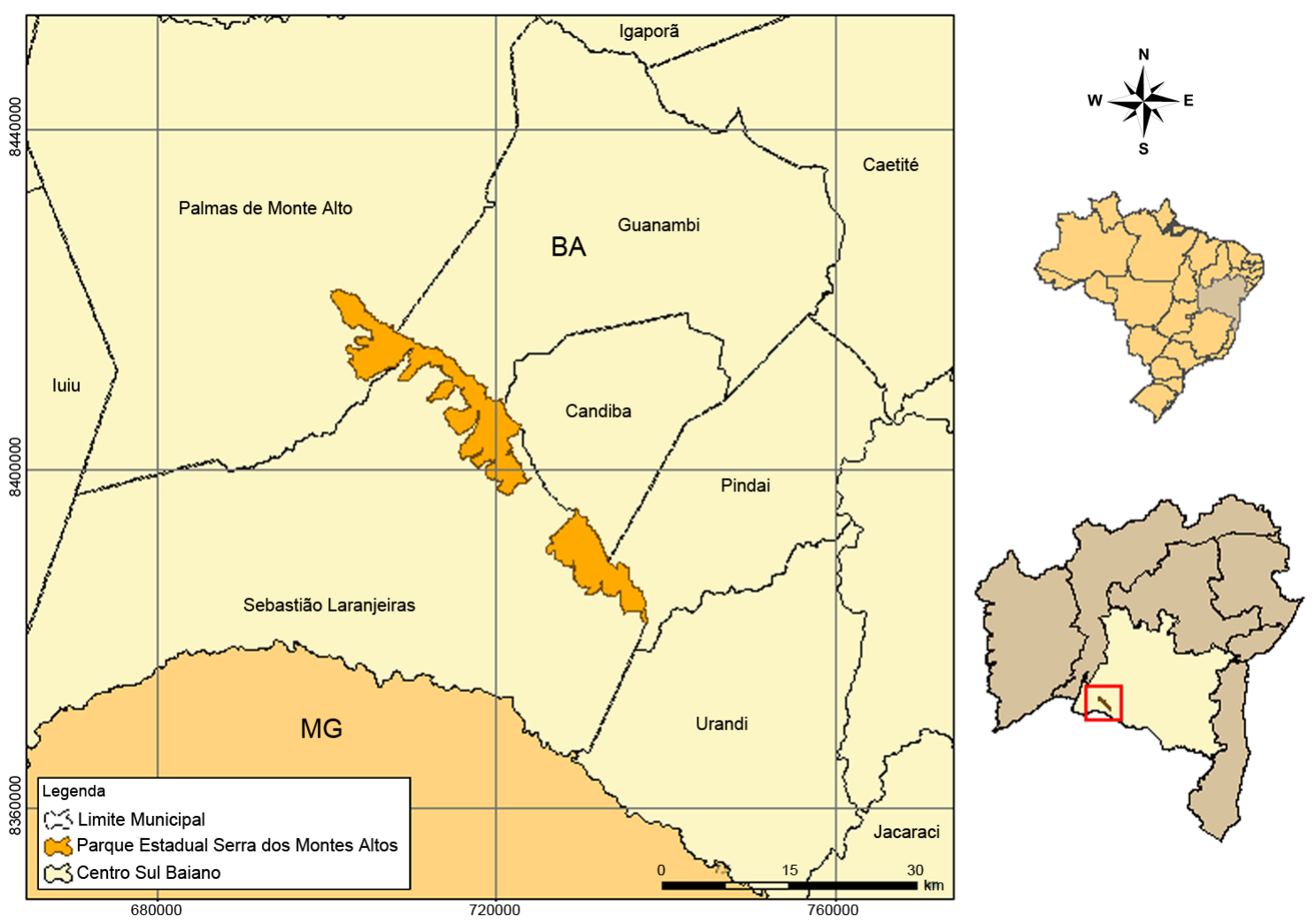

Figura 1 - Localização da Serra dos Montes Altos, Bahia, Brasil (Adaptado de Soares Filho 2012).

Figure 1 - Location of Serra dos Montes Altos, Bahia, Brazil (Adapted from Soares Filho 2012).

tipos vegetacionais encontrados no PESMA. As amostras foram processadas seguindo as técnicas usuais de herborização (Mori et al. 1985) e depositadas no herbário da Universidade do Estado da Bahia (HUNEB - Coleção Caetité). Foram analisados também espécimes pertencentes ao acervo dos herbários HUEFS da Universidade Estadual de Feira de Santana, HUNEB - Coleção Caetité da Universidade do Estado da Bahia e do HUESBVC da Universidade Estadual do Sudoeste da Bahia.

A identificação das espécies foi realizada com o auxílio de chaves analíticas encontradas em obras clássicas, floras regionais e revisões taxonômicas (e.g., Lewis 1987; Barneby 1991; Queiroz 2009; Santos-Silva et al. 2015), diagnoses originais e por comparação com imagens de coleções-tipo disponíveis na internet (sites do The New York Botanical Garden, Muséum National d'Histoire Naturelle, Missouri Botanical Garden e Royal Botanic Gardens). As descrições se basearam nos espécimes analisados e a padronização da terminologia dos caracteres vegetativos e reprodutivos foi baseada em Radford et al. (1974) e referências específicas em Leguminosae. Para determinar a forma dos frutos foi utilizado Barroso et al. (1999). Os comentários sobre distribuição geográfica geral dos táxons foram baseados na literatura e no site da Flora do Brasil 2020 em construção (http:// floradobrasil.jbrj.gov.br/), enquanto a ocorrência das espécies no PESMA foi determinada através de observações nas trilhas percorridas e análise das etiquetas dos espécimes analisados.

\section{Resultados e Discussão}

No Parque Estadual da Serra dos Montes Altos, o clado Mimosoide está representado por 16 espécies distribuídas em oito gêneros (Figs. 3-7). Mimosa L., com sete espécies, foi o gênero mais representativo, seguido por Calliandra Benth. com três, enquanto que os demais, Enterolobium Mart., Inga Mill., Lachesiodendron P.G. Ribeiro, L.P. Queiroz \& Luckow, Pityrocarpa Britton \& Rose, Pseudopiptadenia Rausch. e Senegalia Raf., estão representado por uma espécie cada. 


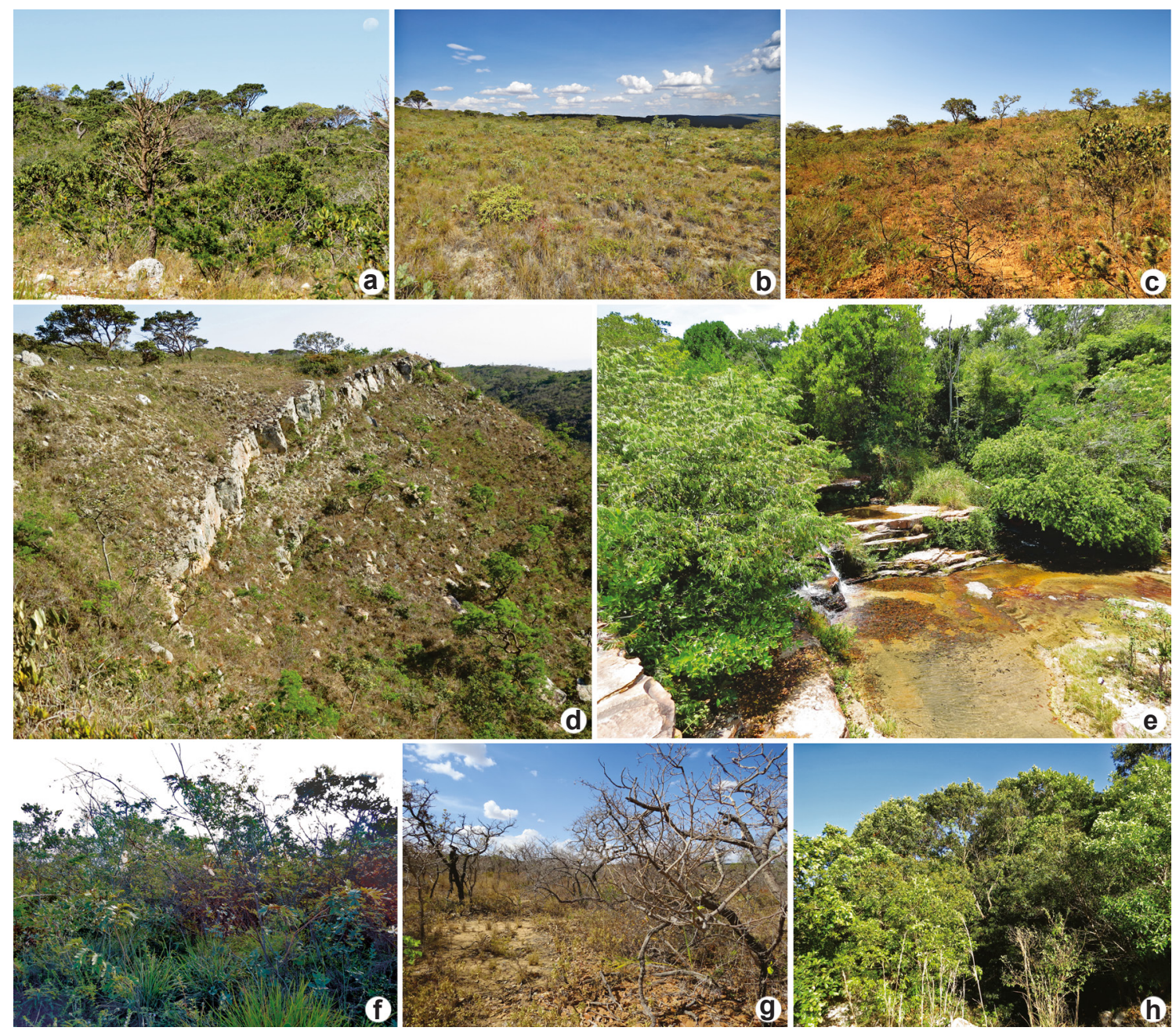

Figura 2 - Vegetação do Parque Estadual da Serra dos Montes Altos, Bahia, Brasil - a. Cerrado; b. Cerrado campo limpo; c. Cerrado campo sujo; d. Campo rupestre; e. Floresta ribeirinha; f. Caatinga; g. Floresta decidual (Mata seca); h. Mata de Galeria. (Fotos: J.M.S. Freire Júnior).

Figure 2 - Vegetation of State Park of the Serra dos Montes Altos, Bahia, Brazil - a. Cerrado; b. Cerrado campo limpo (grasslands with scant or no bushes or trees); c. Cerrado campo sujo (grasslands with the occasional presence of bushes); d. Rupestrian fields; e. Riverine forest; f. Caatinga; g. Decidous forest (Dry forest); h. Gallery forest. (Image: J.M.S. Freire Júnior).

A maioria dos táxons registrados é endêmica do Brasil, onde ocorrem predominantemente nos domínios fitogeográficos da Caatinga e do Cerrado, com exceção de Mimosa acutistipula (Mart.) Benth., M. pithecelobioides Benth. e Pityrocarpa moniliformis (Benth.) Luckow \& R.W. Jobson que também podem ser encontradas nos domínios da Mata Atlântica e Amazônia.

Grande parte dos representantes do clado Mimosoide ocorre no PESMA em vegetação de Cerrado, geralmente sobre solo arenoso, às vezes associado à Caatinga ou Campo rupestre.
Enterolobium gummiferum (Mart.) J.F. Macbr., Inga laurina (Sw.) Willd. e Lachesiodendron viridiflorum (Kunth) P.G. Ribeiro, L.P. Queiroz \& Luckow crescem em florestas ripárias. Apenas Calliandra leptopoda Benth. e Pityrocarpa moniliformis foram encontradas em vegetação de Caatinga e, Pseudopiptadenia brenanii G.P. Lewis \& M.P. Lima em Floresta Estacional Decidual.

Os principais caracteres diagnósticos para a distinção dos táxons são o número de folíolos, forma e localização de nectários, tipo de inflorescência, morfologia dos frutos e sementes. 
Chave para os gêneros do clado Mimosoide ocorrentes no Parque Estadual Serra de Montes Altos, Bahia, Brasil

1. Folhas pinadas; semente com arilo

3. Inga

1'. Folhas bipinadas; sementes sem arilo.

2. Folhas sem nectários extraflorais.

3. Flores isostêmones ou diplostêmones; estames livres; fruto craspédio

5. Mimosa

3'. Flores polistêmones; estames monadelfo; fruto legume típico

1. Calliandra

2'. Folhas com nectários extraflorais no pecíolo e/ou na raque.

4. Flores polistêmones reunidas em glomérulos.

5. Ramos inermes; estípulas caducas; androceu monadelfo; legume bacoide auriculiforme

2. Enterolobium

5'. Ramos aculeados; estípulas persistentes; androceu com estames livres; fruto legume típico

8. Senegalia

4'. Flores diplostêmones reunidas em espigas.

6. Nectários localizados apenas na raque foliar; anteras desprovidas de glândula apical 5. Mimosa

6'. Nectários localizados no pecíolo e/ou na raque; anteras com glândula apical.

7. Ramos armados com espinhos nodais aos pares; fruto legume típico

4. Lachesiodendron

7’. Ramos inermes; fruto folículo.

8. Folhas com 1-3 pares de folíolos; ramos glabrescente; semente não alada ...

6. Pityrocarpa

8'. Folhas com 3-4 pares de folíolos; ramos velutinos; semente alada

7. Pseudopiptadenia

1. Calliandra Benth., J. Bot. 2: 138. 1840, nom. conserv.

Gênero de distribuição neotropical, com aproximadamente 135 espécies, reconhecido pelo hábito arbustivo a arbóreo, folhas bipinadas, estames monadelfos e frutos com margens espessas e deiscência elástica do ápice para a base (Barneby 1998). Para Brasil são registradas aproximadamente 74 espécies que geralmente ocorrem associadas a áreas secas ou com forte sazonalidade (BFG 2018; Queiroz 2009). Na área de estudo, foram registradas três espécies.

\section{Chave para as espécies de Calliandra ocorrentes no Parque Estadual Serra de Montes Altos, Bahia, Brasil}

1. Arbusto com ca. 1,5m de alt.; folhas com 4-7 pares de folíolos; flores tetrâmeras

2. Calliandra nebulosa

1'. Subarbusto com até $1 \mathrm{~m}$ de alt.; folhas com 1 par de folíolos; flores pentâmeras.

2. Estípulas 3-7 mm compr., lanceoladas, não foliáceas; pecíolo $1-3 \mathrm{~mm}$ compr.; flores sésseis .... 3. Calliandra sessilis

2'. Estípulas 9-20 mm compr., cordiformes, foliáceas; pecíolo 1-2 cm compr.; flores pediceladas .. 1. Calliandra leptopoda

1.1. Calliandra leptopoda Benth., London J. Bot. 3: 101.1844.

Subarbusto $0,5-1 \mathrm{~m}$ alt.; ramos cilíndricos, inermes, não estriados, não lenticelados, marrons, pubérulos; tricomas granulares avermelhados esparsos; braquiblasto ausente. Estípulas 9-20 mm compr., cordiformes, foliáceas, não ciliadas, não adnatas ao caule, persistentes. Folhas bipinadas,
1 par de folíolos; pecíolo 1-2 cm compr., glabro; nectário extrafloral ausente; espícula interpinal ausente; parafilídio ausente; ráquila 1,8-4 cm compr.; foliólulos $4-5$ pares, $1-2 \times$ 0,6-1 cm, membranáceos, oblongo-elípticos, base semicordada, ápice arredondado ou obtuso, margem não ciliada, glabros, sem pontuação glandular; nervação palminérvea. Umbelas homomórficas, 
4-5-fasciculadas, pedunculadas, agrupadas em pseudoracemos, terminais, não emergindo de braquiblastos; pedúnculo 1,5-3 cm compr.; bráctea ausente; bractéolas 1-1,5 mm compr., lanceoladas, não estriadas, persistentes. Flores homomórficas, pentâmeras, pediceladas; pedicelo $0,8-1,2 \mathrm{~cm}$ compr.; cálice $0,6-1 \mathrm{~cm}$ compr., campanulado, não estriado, glabro, lobos deltoides; corola $2-2,5 \mathrm{~cm}$ compr., campanulada, não estriada, pubérula, com tricomas granulares, lacínias oblongas, vináceas; estames numerosos, filetes 5-7 mm compr., unidos, vináceos, tubo estaminal 1-2 mm compr., anteras sem glândula apical; disco nectarífero presente; ovário 1-1,5 mm compr., subséssil, estilete $0,5-1$ $\mathrm{mm}$ compr. Legumes 6-7 × 0,9-1 cm, oblongos, sésseis, base atenuada, ápice mucronado, cartáceos, marrons, glabros. Sementes ca. $6 \times 4 \mathrm{~mm}$, elipsoides, sem arilo, não aladas, castanhas.

Material examinado: Palmas de Monte Alto, Serra dos Montes Altos, entrada para o Brucunum, área de caatinga, 25.I.2007, fl. e fr., A.O. Soares Filho \& R.C.S. Carvalho 85 (HUESBVC).

Espécie endêmica do Brasil, onde ocorre nos estados da Bahia, Minas Gerais, Pernambuco e Piauí, crescendo em vegetação de Caatinga (Souza 2015; BFG 2018). No PESMA foi verificada em área de Caatinga, sobre solos arenosos. Floresce em janeiro.

Calliandra leptopoda difere das demais espécies ocorrentes no PESMA por possuir estípulas cordiformes, foliáceas, com 9-20 mm de comprimento, folhas com um par de folíolos e 4-5 pares de foliólulos oblongo-elípticos e flores com pedicelo longo ( $0,8-1,2 \mathrm{~cm}$ compr.). Pode ser confundida com $C$. sessilis, devido ao hábito subarbustivo, número de pares folíolos (um par) e flores pentâmeras. Entretanto, pode ser diferenciada principalmente pelo tamanho da estípula (9-20 mm compr. vs. 3-7 mm compr. em C. sessilis) e coloração dos filetes (vináceos vs. alvos na base e róseos a roxos na porção terminal). Ilustrações em Queiroz (2009).

1.2. Calliandra nebulosa Barneby, Mem. New York Bot. Gard. 74(3): 150. 1998. Figs. 3a-d; 7a

Arbusto ca. 1,5 m alt.; ramos cilíndricos, inermes, não estriados, não lenticelados, castanhoacinzentados, densamente velutinos; tricomas tectores e granulares, persistentes ou caducos; braquiblasto ausente. Estípulas 3-4 mm compr., ovais a lanceoladas, não foliáceas, não ciliadas, não adnatas ao caule, persistentes. Folhas bipinadas, 4-7 pares de folíolos; pecíolo 1,5-4,5 mm compr., inerme, velutino; raque $2,5-3,8 \mathrm{~cm}$ compr., 2 -costadas ventralmente, inerme, não alada; nectário extrafloral ausente; espícula interpinal ausente; parafilídio ausente; ráquila $2-4,5 \mathrm{~cm}$ compr.; foliólulos 15-25 pares, 3,5-5 × 1-1,5 mm, coriáceos, linear-oblongos, base oblíqua, ápice arredondado, margem esparso-ciliada, pubérulos, com tricomas granulares, sem pontuação glandular; nervação hifódroma. Glomérulos homomórficos, 2-4-fasciculados, pedunculados, agrupados em pseudoracemos terminais, não ultrapassando as folhagens, não emergindo de braquiblastos; pedúnculos $2-5 \mathrm{~cm}$ compr.; bráctea ausente; bractéolas $0,2-0,5 \mathrm{~mm}$ compr., ovais, não estriadas, caducas. Flores homomórficas, tetrâmeras, sésseis a subsésseis; cálice 1-2,5 mm compr., campanulado, pubérulo com tricomas granulares, lobos deltoides; corola 5-8,5 mm compr., campanulada, estriada, glabra, lacínias agudas a ovais, vinácea; estames numerosos, filetes $2-3 \mathrm{~cm}$ compr., unidos, brancos ou róseos, tubo estaminal 5-9 $\mathrm{mm}$ compr., anteras sem glândula apical; disco nectarífero ausente; ovário 1,5-2 mm compr., séssil, estilete 2-3,5 $\mathrm{mm}$ compr. Legumes 5-7 $\times 0,5-1 \mathrm{~cm}$, oblongos a oblanceolados, sésseis, ápice agudo ou mucronado, base cuneada, lenhosos, castanho-ferrugíneos, pubérulos. Sementes 5-8 × 4-4,5 mm, obovóides, sem arilo, não aladas, marrom-escuro.

Material examinado: Candiba, Parque Estadual da Serra dos Montes Altos, 30.IV.2015, fr. e fr., J.M.S. FreireJúnior 34 (HUNEB - Coleção Caetité); 1.X.2015, fl. e fr., J.M.S. Freire-Júnior 67 (HUNEB - Coleção Caetité). Guanambi, Cabeça d'Anta, 30.XI.2014, fl. e fr., E.C. Costa \& J.S. Nascimento 269 (HUNEB - Coleção Caetité).

É endêmica do estado da Bahia, onde se distribui na Serra do Espinhaço, em altitudes que variam de 950 a $1.100 \mathrm{~m}$, sobre vegetação de Campo rupestre, Campo limpo, Carrasco e Cerrado (Souza 2015; BFG 2018). Na área de estudo, foi encontrada em áreas de Cerrado, sobre solo arenoso. Floresce e frutifica nos meses de maio, outubro e novembro.

Calliandra nebulosa possui hábito arbustivo, diferenciando-se das demais espécies congenéricas pelos ramos velutinos, folhas com 4-7 pares de folíolos, foliólulos linear-oblongos e pelas flores tetrâmeras com filetes brancos ou róseos.

1.3. Calliandra sessilis Benth., J. Bot. (Hooker) 2: 141. 1840.

Figs. 3e-g; 7b

Subarbusto $0,3-1 \mathrm{~m}$ alt.; ramos cilíndricos, inermes, não estriados, não lenticelados, marrons, pubérulos; tricomas granulares; braquiblastos 

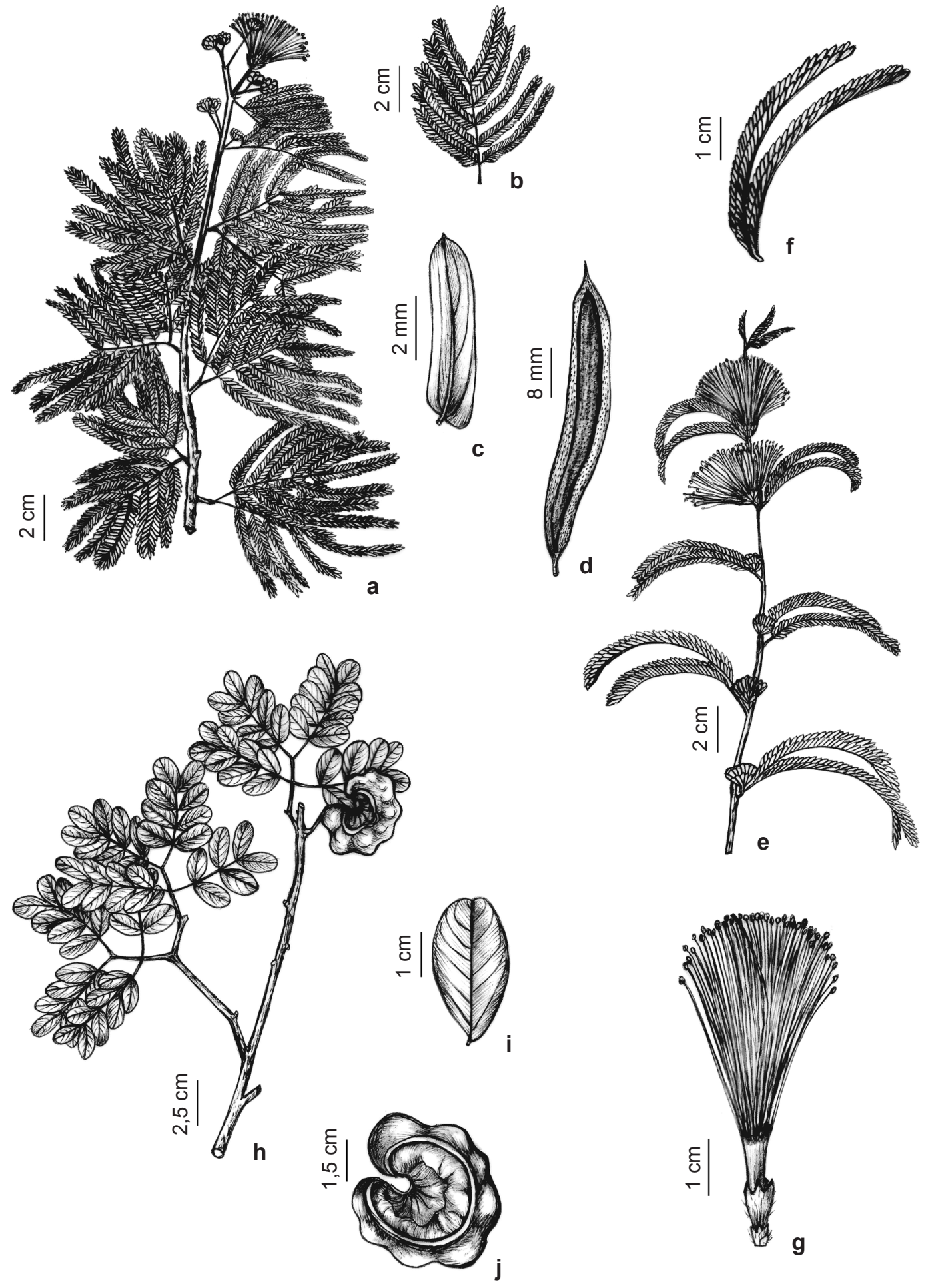

Figura 3 - a-d. Calliandra nebulosa - a. ramo; b. folha; c. detalhe do foliólulo; d. fruto. e-g. C. sessilis - e. ramo; f. folha; g. detalhe da flor. h-j. Enterolobium guminferum - h. ramo; i. detalhe do foliólulo; j. fruto. (a-d J.M.S. FreireJúnior 67; e-g J.M.S. Freire-Júnior 85; h-j J.M.S. Freire-Júnior 77)

Figure 3 - a-d. Calliandra nebulosa - a. branch; b. leaf; c. detail of the leaflet; d. fruit. e-g. C. sessilis - e. branch; f. leaf; g. detail of the flower. h-j. Enterolobium guminferum - h. branch; i. detail of the leaflet; j. fruit. (a-d J.M.S. Freire-Júnior 67; e-g J.M.S. Freire-Júnior 85; h-j J.M.S. Freire-Júnior 77) 
axilares envolvidos por profilos setiformes imbricados na base, 5-10 mm compr.. Estípulas 3-7 mm compr., lanceoladas, não foliáceas, não ciliadas, não adnatas ao caule, persistentes. Folhas bipinadas, 1 par de folíolos; pecíolo 1-3 mm compr., inerme, pubérulo; nectário extrafloral ausente; espícula interpinal ausente; parafilídio ausente; ráquila 3-6 cm compr.; foliólulos 17-33 pares, 7-12 × 2-4 mm, coriáceos, oblongos a lanceolados, base oblíqua ou semicordada, ápice arredondado a agudo, margem não ciliada, pubérulos, com tricomas granulares; sem pontuação glandular; nervação palminérvea. Glomérulos heteromórficos, solitários, sésseis, axilares, emergindo de braquiblastos; brácteas 2-3 mm compr.; bractéola 1,5-2 mm compr., oblongas, estriadas, persistentes. Flores heteromórficas, pentâmeras, sésseis; flores marginais com cálice 2,5-3,8 mm compr., campanulado, estriado, pubérulo, com tricomas granulares, lobos deltoides; corola 4-6 mm compr., campanulada, não estriada, pubérula, com tricomas granulares, lacínias agudas, rósea; estames numerosos, filetes 2-2,5 cm compr., unidos, bicolores, alvos na base e róseos a roxos na porção terminal, tubo estaminal 0,5-1 cm compr., anteras sem glândula apical; disco nectarífero ausente; ovário 1-2 mm compr., glabro. Flores centrais com cálice $3-5 \mathrm{~mm}$ compr., campanulado, estriado, pubérulo, lobos deltoides; corola 6-8 mm compr., campanulada, estriada, lacínias oblongas, ciliadas, alva; estames numerosos, filetes $2,5-3 \mathrm{~cm}$ compr., unidos, bicolores, alvos na base e róseos a roxos na porção terminal, tubo estaminal 1,3-1,7 cm compr., anteras sem glândula apical; disco nectarífero presente; ovário 1,5-2 mm compr., séssil, estilete 2-3 cm compr.. Fruto não observado.

Material examinado: Palmas de Monte Alto, Serra dos Montes Altos, entrada para o Brucunum, 26.I.2007, fl., A.O. Soares Filho \& R.C.S. Carvalho 133 (HUESBVC). Candiba, Parque Estadual da Serra dos Montes Altos, 8.II.2016, fl., J.M.S. Freire-Júnior 85 (HUNEB - Coleção Caetité).

Espécie com ampla distribuição no Brasil, ocorrendo nas regiões Norte (Pará), Nordestes (Bahia, Ceará, Maranhão, Pernambuco e Piauí), Centro-oeste (Mato Grosso do Sul) e Sudeste (Minas Gerais). É encontrada em vegetações de Cerrado, Campo rupestre e Caatinga, em altitudes que variam de 600 a 1.200 m (Souza 2015; BFG 2018). Na área de estudo, Calliandra sessilis é encontrada crescendo em áreas de Cerrado e Campo rupestre. Floresce em janeiro e fevereiro.
Dentre as espécies de Calliandra encontradas no PESMA, C. sessilis é a única com inflorescência séssil, flores heteromóficas, sésseis e filetes bicolores (alvos na base e róseo a roxo na porção terminal).

2. Enterolobium Mart., Flora 20 (2): 117. 1837.

É constituído por apenas 10 espécies distribuídas desde o sul do México até a Argentina (Barneby \& Grimes 1996). No Brasil, está representado por nove espécies amplamente distribuídas ao longo dos domínios fitogeográficos da Amazônia, Caatinga, Cerrado e Mata atlântica (BFG 2018; Mesquita et al. 2018). No PESMA, ocorre apenas uma espécie associada às formações florestais e às áreas de Cerrado.

Enterolobium é facilmente reconhecido pelo tipo de fruto, que é indeiscente, internamente septado, com o corpo fortemente recurvado.

2.1. Enterolobium gummiferum (Mart.) J.F. Macbr., Contr. Gray Herb. 59: 1. 1919.

Figs. 3h-j; $7 \mathrm{c}$

Árvore ca. $3 \mathrm{~m}$ alt.; ramos cilíndricos, inermes, com súber espesso e estrias profundas, lenticelados, castanhos a acinzentados, pubérulos; tricomas tectores esbranquiçados; braquiblasto ausente. Estípulas caducas. Folhas bipinadas, 2-3 pares de folíolos; pecíolo 2,5-5 cm compr., inerme, pubérulo; raque $2-5 \mathrm{~cm}$ compr., cilíndrica, inerme, não alada; nectários extraflorais na base do pecíolo e no ápice da raque, verruciformes ou cupuliformes, sésseis, persistentes; espícula interpinal ausente; parafilídio ausente; ráquila 5-8 cm compr.; foliólulos 4-6 pares, 2-3,5 × 1-2 cm, cartáceos, oblongos, base aguda, ápice arredondado a emarginado, margem não ciliada, glabros, sem pontuação glandular; nervação peninérvea, nervuras secundárias proeminentes na face adaxial. Glomérulos homomórficos, solitários ou 2-fasciculados, pedunculados, axilares, não emergindo de braquiblastos; pedúnculo 2-3 cm compr.; bráctea ausente; bractéolas ca. $0,3 \mathrm{~mm}$ compr., ovais, não estriadas, caducas. Flores homomórficas, pentâmeras, sésseis ou subsésseis; pedicelo 0,5-1 $\mathrm{mm}$ compr.; cálice 1,8-2,5 mm compr., campanulado, pubérulo, lobos agudos, 1-nervados; corola 4-7 mm compr., infundibuliforme, glabrescente, lacínias agudas, 1-nervadas, verde-amareladas; estames numerosos, filetes $8-9 \mathrm{~mm}$ compr., unidos na base, brancos, tubo estaminal 2,5-3 mm compr., anteras sem glândula apical; disco nectarífero ausente; ovário 
1,8-2 mm compr., estipitado, estípite ca. 0,2 mm compr., estilete 1-1,3 mm compr. Legumes bacoides 7-9,8 × 3-5,2 cm, auriculiformes, sésseis, base e ápice arredondado, túrgidos na região das sementes e constritos entre elas, lenhosos, rugosos, acinzentados, velutinos. Sementes $1-1,5 \times 0,7-1,2$ $\mathrm{cm}$, obovóides, sem arilo, não aladas, marrons.

Material examinado: Palmas de Monte Alto, Parque Estadual da Serra dos Montes Altos, 5.XII.2015, fr., J.M.S. Freire-Júnior 77 (HUNEB - Coleção Caetité). Sebastião Laranjeira, Serra de Monte Alto, 8.IX.2006, fl. e fr., O.A. Soares Filho 9 (HUESBVC).

Espécie endêmica do Brasil com ampla distribuição nos estados do Bahia, Goiás, Mato Grosso, Mato Grosso do Sul, Maranhão, Minas Gerais, Pará, Piauí, Tocantins, São Paulo e no Distrito Federal, em vegetação de Cerrado e Savana amazônica (BFG 2018; Mesquita et al. 2018). No PESMA foi encontrada em margem de curso d'água e em vegetação de Cerrado sobre solo arenoso a $1.000 \mathrm{~m}$ de altitude. Floresce em setembro e frutifica nos meses de setembro e dezembro.

Enterolobium gummiferum pode ser reconhecida, mesmo em sua fase vegetativa, pelo caule com súber proeminentemente espesso e profundamente estriado e pelas folhas com 2 a 3 pares de folíolos e foliólulos com 2-3,5 $\times$ 1-2 cm. Quando em fruto, pode ser facilmente reconhecida pelo legume bacoide auriculiforme, com indumento velutino.

3. Inga Mill., Gard. Dic. Abr. (ed. 4) no. 2. 1754. Inga, com cerca de 300 espécies, pode ser facilmente identificado por apresentar folhas paripinadas com nectários conspícuos entre os pares de folíolos. Suas espécies ocorrem nas Florestas tropicais e subtropicais, do sul do México até o Uruguai, no sul da América do Sul (Pennington 1997). Estima-se que ocorram no Brasil aproximadamente 132 espécies, das quais 51 são endêmicas (BFG 2018). Na área de estudo, está representado por apenas uma espécie.

3.1. Inga laurina (Sw.) Willd., Sp. Pl., ed. 4(2): 1018. 1806.

Figs. 4a-c; 7d

Árvore ca. $7 \mathrm{~m}$ alt.; ramos cilíndricos, inermes, não estriados, esparsamente lenticelados, acinzentados, glabros; braquiblasto ausente. Estípulas 3-5 mm compr., lanceoladas, não foliáceas, não ciliadas, não adnatas ao caule, persistentes. Folhas paripinadas, 2 pares de folíolos; pecíolo 1-2 cm compr., vestigialmente alado, inerme, glabro; raque 1,5-4 cm compr., alada, inerme, alas levemente proeminentes, 1-2 mm larg.; nectários extraflorais entre cada par de folíolos, côncavos, sésseis, persistentes; espícula interpinal ausente; parafilídio ausente; folíolos heteromórficos, 5-15 ×2-5 cm, coriáceos, oblongoelípticos, base cuneada, ápice atenuado, margem não ciliada, glabros, sem pontuação glandular; nevarção reticulódroma ou broquidódroma. Espigas cilíndricas, homomórficas, solitárias ou 2-fasciculadas, pedunculadas, axilares, não emergindo de braquiblastos; pedúnculo $1-2 \mathrm{~cm}$ compr.; brácteas e bractéolas não observadas. Flores homomórficas, pentâmeras, sésseis; cálice 0,5-1,5 mm compr., infundibuliforme, não estriado, glabrescente, lobos agudos; corola 3-5 mm compr., tubulosa, não estriada, glabra, lacínias agudas, verde-claro a brancas; estames ca. 41 , filetes $1-1,5 \mathrm{~cm}$ compr., unidos, brancos, tubo estaminal 3-4 mm compr., anteras sem glândula apical; disco nectarífero ausente; ovário 1,5-2 mm compr., séssil, estilete 0,9-1,6 cm compr. Legumes 4-9 × 2-3 cm, oblongos, sésseis, ápice e base aguda, coriáceos, nervuras transversais proeminentes, amarelos, glabros. Sementes 1-1,5 $\times$ ca. $0,5 \mathrm{~cm}$, elípticas, arilo abundante, não aladas, verdes.

Material examinado: Palmas de Monte Alto, riacho Sambaíba, Fonte da Nega, 20.IV.2007, fl., A.O. Soares Filho 253 (HUESBVC); cachoeira da Mandiroba, 30.XI.2015, fr., J.M.S. Freire-Júnior 78 (HUNEB Coleção Caetité). Sebastião Laranjeiras, cachoeira da Catindiba, 13.I.2015, fl., E.C. Costa \& J.S. Nascimento 299 (HUNEB - Coleção Caetité).

Apresenta ampla distribuição, ocorrendo em praticamente toda América Central (do México ao Panamá) e América do Sul (da Colômbia ao norte da Argentina) (Pennington 1997). No Brasil ocorre em todas as regiões, exceto na Região Sul. Cresce em áreas de Campo rupestre, Floresta Estacional Semidecidual, Floresta Ombrófila e Restinga (Garcia \& Fernandes 2015; BFG 2018). No PESMA, I. laurina foi coletada em Mata ciliar (Floresta Estacional Semidecidual Ribeirinha), sobre afloramento rochoso. Flores foram observadas em janeiro e abril, e frutos em novembro.

Inga laurina é facilmente distinta das outras espécies do clado Mimosoide ocorrente na área de estudo por apresentar folhas paripinadas com um nectário entre cada par de folíolos e pelos frutos amarelos cujas sementes apresentam abundante arilo. 


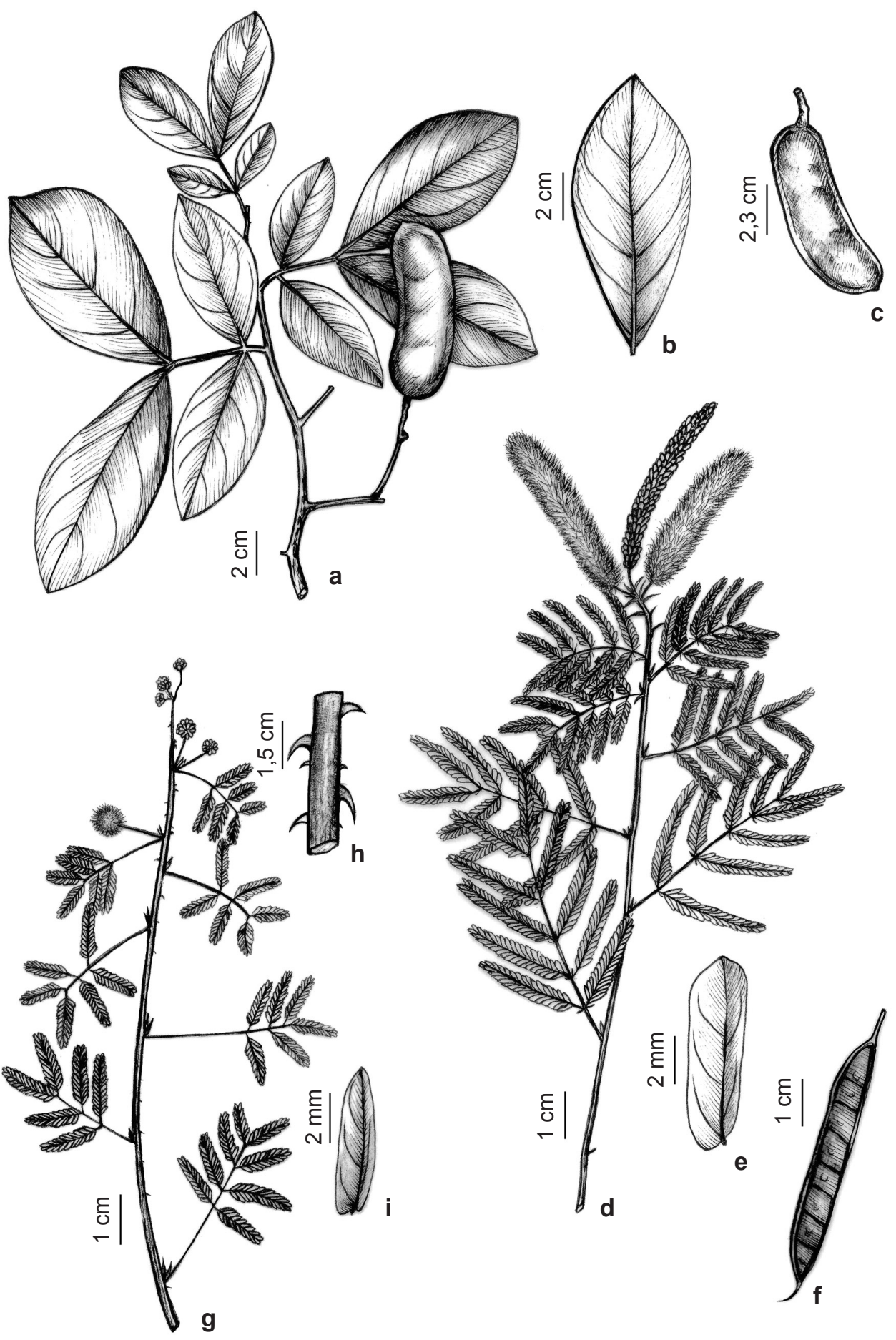

Figura 4 - a-c. Inga laurina - a. ramo; b. detalhe do folíolo; c. fruto. d-f. Mimosa acutistipula var. acutistipula - d. ramo; e. detalhe do foliólulos; f. fruto. g-i. M. campicola var. planipes - g. ramo; h. detalhe dos acúleos; i. detalhe do foliólulo. (a-c J.M.S. Freire-Júnior 78; d-e J.M.S. Freire-Júnior 86; f. A. Sanches \& J. Perfeito 284; g-i J.M.S. Freire-Júnior 36)

Figure 4 - a-c. Inga laurina - a. branch; b. detail of the leaflet; c. fruit. d-f. Mimosa acutistipula var. acutistipula - d. branch; e. detail of the leaflet; f. fruit. g-i. M. campicola var. planipes - g. branch; h. detail of the aculeos; i. detail of the leaflet. (a-c J.M.S. Freire-Júnior 78; d-e J.M.S. Freire-Júnior 86; f. A. Sanches \& J. Perfeito 284; g-i J.M.S. Freire-Júnior 36) 
4. Lachesiodendron P.G. Ribeiro, L.P. Queiroz \& Luckow, Taxon 67(1): 45. 2018.

Gênero monoespecífico com distribuição na América Central e na América do Sul, onde cresce em áreas de Florestas e arbustais tropicais sazonalmente secos - FATSS ou SDTFW na sigla em inglês (Ribeiro et al. 2018). A sua únca espécie, Lachesiodendron viridiflorum (Kunth) P.G.Ribeiro, L.P. Queiroz \& Luckow até recentemente pertencia ao gênero Piptadenia Benth., mas foi transferida para Lachesiodendron com base em evidências moleculares e morfológicas.

Lachesiodendron diferencia-se de Piptadenia principalmente pela presença de espinhos pareados na base da folha (estípulas modificadas) (vs. ramos inermes ou espinhos dispersos nos ramos), espigas axilares 1-2 (3), não agrupadas em inflorescência composta ( $v s$. espigas agrupadas em pseudoracemos ou panículas) e corola cilíndrica ( $v s$. corola campanulada).

4.1. Lachesiodendron viridiflorum (Kunth) P.G. Ribeiro, L.P. Queiroz \& Luckow, Taxon 67(1): 45-51. 2018. Figs. 6a-d; $7 \mathrm{i}$

Árvore 4-10 m alt.; ramos costados, espinescentes, não estriados, densamente lenticelados, acinzentados, glabros; espinhos pareados em cada nó, ligeiramente a fortemente recurvados; braquiblasto ausente. Estípulas espinescentes. Folhas bipinadas, 4-8 pares de folíolos; pecíolo 3-5 cm compr., inerme, glabro; raque $4-10 \mathrm{~cm}$ compr., cilíndrica, inerme, não alada; nectários extraflorais no pecíolo e entre o par de folíolos distais discoides, sésseis, persistentes; espícula interpinal ausente; parafilídio ausente; ráquila $3-8 \mathrm{~cm}$ compr.; foliólulos 24-32 pares, 4-7 × 1-3 mm, cartáceos, base obliquamente cordada, ápice obtuso, margem não ciliada, glabros, sem pontuação glandular; nervação peninérvea, nervura principal excêntrica, nervuras secundárias proeminentes na face adaxial. Espigas cilíndricas, homomórficas, 2-3-fasciculadas, pedunculadas, axilares, não emergindo de braquiblastos; pedúnculo 1,5-2,3 cm compr.; bráctea ausente; bractéola não observada. Flores homomórficas, pentâmeras, sésseis a subsésseis; cálice 3-5 mm compr., campanulado, não estriado, pubérulo, lobos agudos; corola 4-7,2 $\mathrm{mm}$ compr., infundibuliforme, não estriada, brancaamarelada, glabrescente, lacínias lanceoladas; estames 10 , filetes $0,8-1,2 \mathrm{~cm}$ compr., livres, róseos a verde-amarelados, anteras com glândula apical caduca; disco nectarífero ausente; ovário 3-4,2 mm compr., estipitado, estípite 3-3,5 $\mathrm{mm}$ compr., estilete $3-6,3 \mathrm{~mm}$ compr. Legume $10-11 \times 1,5-2 \mathrm{~cm}$, oblongo-lineares, estipitados, plano-compressos, base aguda, ápice agudo ou mucronado, castanhos, glabros. Sementes não observadas.

Material examinado: Palmas de Monte Alto, Serra de Monte Alto, mata de galeria do rio Espinho, 9.IX.2006, fl., A.O. Soares Filho 56 (HUESBVC). Sebastião Laranjeiras, Parque Estadual da Serra dos Montes Altos, 16.IX.2015, fl. e fr., J.M.S. Freire-Júnior 70 (HUNEB - Coleção Caetité).

Ocorre na Argentina, Bolívia, Brasil, Colômbia, Equador, Guatemala, México, Peru e Venezulela (Prado \& Gibbs 1993; Ribeiro et al. 2018). No Brasil tem ocorrências confirmadas em grande parte do Nordeste (Alagoas, Bahia, Ceará, Paraíba, Pernambuco, Piauí, Rio Grande do Norte, Sergipe), em Minas Gerais e Mato Grosso do Sul, onde cresce em vegetação de Caatinga, Cerrado e Floresta Estacional Decidual (BFG 2018). No PESMA foi encontrada em margem de curso d'água. Flores e frutos foram observados em setembro.

Lachesiodendron viridiflorum pode ser reconhecida por ser uma árvore com estípulas espinescentes, folhas 24-32-folioluladas, espigas cilíndricas e frutos estipitados.

\section{Mimosa L., Sp. Pl. 516.1753.}

$\mathrm{O}$ gênero possui distribuição pantropical e é constituído por 540 espécies (Barneby 1991; Simon et al. 2011), sendo o segundo maior gênero do clado Mimosoide. Destaca-se ainda por ser o segundo gênero mais diverso da flora de angiospermas do Brasil, com aproximadamente 365 espécies (BFG 2018). No PESMA, foram registradas sete espécies.

Caracteriza-se pelo hábito variável, folhas bipinadas predominantemente sem nectários, flores isostêmones ou diplostêmones, sem glândulas no ápice das anteras e frutos sacelo ou craspédio articulado ou não articulado. 


\section{Chave para espécies de Mimosa ocorrentes no Parque Estadual Serra de Montes Altos, Bahia, Brasil}

1. Nectários extraflorais presentes entre os pares de folíolos proximais ... 5.6. Mimosa pithecolobioides

1'. Nectários extraflorais ausentes.

2. Folhas com apenas 1 par de folíolos; flores isostêmones 5.4. Mimosa hypoglauca

2'. Folhas com mais de 1 par de folíolos; flores diplostêmones.

3. Espigas globosas.

4. Ramos glabros; flores trímeras, lacínias da corola 1-nervadas

5.2. Mimosa campicola

4'. Ramos pubescentes; flores tetrâmeras, lacínias da corola 7-10-nervadas

5.7. Mimosa somnians

3'. Espigas cilíndricas.

5. Ramos inermes; foliólulos com glândulas lentiformes na face abaxial; filetes róseos .. 5.3. Mimosa gemmulata

5'. Ramos aculeados; foliólulos sem pontuação glandular; filetes esbranquiçados.

6. Corola 4-angulada; ovário e frutos sésseis 5.5. Mimosa ophthalmocentra

6'. Corola campanulada; ovário e frutos estipitados 5.1. Mimosa acutistipula var. acutistipula

5.1. Mimosa acutistipula (Mart.) Benth. var. acutistipula, J. Bot. (Hooker) 4(31): 391. 1841.

Figs. 4d-f; 7e

Arbusto ca. 2,8 m alt.; ramos cilíndricos, aculeados, não estriados, não lenticelados, castanhos a acinzentados, pubérulos; tricomas tectores esbranquiçados; acúleos internodais retos ou ligeiramente recurvados; braquiblasto ausente. Estípulas 4-7 mm compr., subuladas, não foliáceas, não ciliadas, não adnatas ao caule, persistentes. Folhas bipinadas, 3-7(-8) pares de folíolos; pecíolo $0,8-1,5 \mathrm{~cm}$ compr., inerme, pubérulo; raque 3-4,5 cm compr., cilíndrica, inerme, não alada; nectário extrafloral ausente; espículas interpinais triangulares; parafilídios cônicos; ráquila $0,5-1,5$ cm compr.; foliólulos 8-14 pares, 3,5-7 × 1,5-2 $\mathrm{mm}$, cartáceos, oblongos, base obliquamente cordada, ápice agudo, margem ciliada, pubérulos, sem pontuação glandular; 2-nervados, apenas a nervura principal atinge o ápice. Espigas cilíndricas, homomórficas, 2-3-fasciculadas, pedunculadas, axilares ou agrupadas em pseudoracemos terminais, não emergindo de braquiblastos; pedúnculo $0,8-1,5$ cm compr.; bráctea ausente; bractéolas ca. $0,5 \mathrm{~mm}$ compr., oblanceoladas, não estriadas, persistentes. Flores homomórficas, tetrâmeras, sésseis; cálice 0,5-1 mm compr., campanulado, não estriado, glabro, 4-denteado; corola 1,8-2,5 mm compr., campanulada, branca-rosada, glabra, lacínias ovais, 1-nervadas; estames 8 , filetes 5-7 $\mathrm{mm}$ compr., livres, esbranquiçados, anteras sem glândula apical; disco nectarífero ausente; ovário $0,5-1 \mathrm{~mm}$ compr., estipitado, estípite ca. 0,2 mm compr., estilete 4-7 mm compr. Craspédios 5-7 × 0,6-1 cm, oblongos, estipitados, plano-compressos, base atenuada, ápice mucronulado, cartáceos, castanhos a vináceos, glabros a glabrescentes. Sementes 3-4 × ca. $2 \mathrm{~mm}$, ovóides, sem arilo, não aladas, castanhas.

Material examinado: Palmas de Monte Alto, Parque Estadual da Serra de Monte Alto, borda de floresta ribeirinha, 20.IV.2007, fr., A. Sanches \& J. Perfeito 284 (HUESBVC). Sebastião Laranjeiras, Parque Estadual da Serra dos Montes Altos, 8.II.2016, fl., J.M.S. FreireJúnior 86 (HUNEB - Coleção Caetité).

Ocorre no Brasil e na Bolívia (Santos-Silva et al. 2015). Em território brasileiro, é registrada para os estados da Bahia, Ceará, Maranhão, Pernambuco, Piauí e Sergipe, em vegetações Caatinga, Campo Rupestre, Cerrado e Floresta Ombrófila (Santos-Silva et al. 2015). No PESMA, é encontrada em área de Caatinga arbustiva-arbórea associada com Cerrado, em altitude aproximada de $1.000 \mathrm{~m}$. Foi encontrada com flor em fevereiro e com fruto em abril.

Dentre as espécies coletadas no PESMA, Mimosa acutistipula var. acutistipula pode ser confundida com $M$. ophthalmocentra por compartilharem o hábito arbustivo, ramos aculeados, foliólulos sem pontuação glandular e espigas cilíndricas, flores tetrâmeras com filetes esbranquiçados e frutos plano-compressos, no entanto, pode ser diferenciada principalmente pela morfologia da corola (campanulada vs. e 4-angulada 
em M. ophthalmocentra) e do fruto (estipitado vs. séssil). No campo, M. acutistipula var. acutistipula pode ser reconhecida por apresentar os ramos férteis flexuosos pendentes, de maneira que o ápice das espigas e dos frutos ficam voltados para baixo.

5.2. Mimosa campicola var. planipes Barneby, Brittonia 37: 148. 1985.

Figs. 4g-i; $7 \mathrm{f}$

Subarbusto ca. $90 \mathrm{~cm}$ alt., prostrado; ramos angulosos, costados, aculeados, não estriados, não lenticelados, castanhos, glabros; acúleos dispostos em fileiras longitudinais sobre as costelas, recurvados; braquiblasto ausente. Estípulas 2-4 mm compr., subuladas a lanceoladas, não foliáceas, ciliadas, não adnatas ao caule, persistentes. Folhas bipinadas, 3 pares de folíolos; pecíolo 1,5-3 cm compr., aculeado, glabro; raque $0,6-1,2 \mathrm{~cm}$ compr., cilíndrica, aculeada, não alada; nectário extrafloral ausente; espículas interpinais subuladas a lanceoladas; parafilídios cônicos; ráquila $0,9-1$ cm compr.; foliólulos 6-10 pares, 4-6×1-1,5 mm, cartáceos, oblongos, base obliquamente cordada, ápice obtuso ou levemente mucronado, margem ciliada, seríceos, com pontuações glandulares translúcidas; 2-3-nervados, nervura principal subcêntrica. Espigas globosas, homomórficas, solitárias ou 2-fasciculadas, pedunculadas, axilares ou agrupadas em pseudoracemos terminais, não emergindo de braquiblastos; pedúnculo $1-1,3 \mathrm{~cm}$ compr.; bráctea ausente; bractéolas ca. $0,8 \mathrm{~mm}$ compr., lanceoladas, não estriadas, persistentes. Flores homomórficas, trímeras, sésseis; cálice ca. 0,5 mm compr., campanulado, não estriado, glabro, lobos agudos; corola 1,5-2 $\mathrm{mm}$ compr., infundibuliforme, glabra, lacínias ovais, 1-nervadas; estames 6 , filetes 4-5 mm compr., livres, róseos, anteras sem glândula apical; disco nectarífero ausente; ovário ca. $0,9 \mathrm{~mm}$ compr., séssil, estilete 5-6 mm compr. Fruto não observado.

Material examinado: Sebastião Laranjeiras, Parque Estadual da Serra dos Montes Altos, 29.VI.2015, fl., J.M.S. Freire-Júnior 36 (HUNEB - Coleção Caetité).

Espécie com distribuição restrita ao Brasil (Barneby 1991). Ocorre no estado da Bahia (Chapada Diamantina), onde cresce em áreas de Cerrado, Campo rupestre, Caatinga e em áreas de transição Caatinga-Cerrado, sobre solo arenoso (BFG 2018). No PESMA, foi encontrada em vegetação de Cerrado associado a Campo rupestre, sobre solo arenoso. Flores são encontradas em maio.

Mimosa campicola var. planipes pode reconhecida pelos acúleos recurvados, dispostos em fileiras longitudinais sobre as costelas e pelas folhas com 3 pares de folíolos e pelos pecíolos proporcionalmente longos em relação à raque foliar (1,5-3 cm compr. vs. 0,6-1,2 cm compr.). Além disso, é a única espécie de Mimosa que ocorre no PESMA com flores trímeras.

5.3. Mimosa gemmulata Barneby, Brittonia 37: 130. 1985.

Arbusto ou árvore ca. $2 \mathrm{~m}$ alt.; ramos cilíndricos, inermes, não estriados, não lenticelados, castanho-escuros, pubérulos; tricomas tectores amarelados e glandulares sésseis acobreados; braquiblasto ausente. Estípulas 0,5-1 mm compr., triangulares, não foliáceas, não ciliadas, não adnatas ao caule, persistentes. Folhas bipinadas, 7-19 pares de folíolos; pecíolo 2,5-3,5 cm compr., inerme, pubérulo; raque 4,5-9 $\mathrm{cm}$ compr., cilíndrica, inerme, não alada; nectário extrafloral ausente; espículas interpinais triangulares; parafilídios cônicos; ráquila 2-6 cm compr.; foliólulos 16-30 pares, 1,5-2 × 0,5-1,2 mm, cartáceos, oblongos, base obliqua, ápice arredondado, margem ciliada, pubérulos, com tricomas tectores curtos e glândulas lentiformes sésseis na face abaxial; 1-nervados, a nervura principal atingindo o ápice. Espigas cilíndricas, homomórficas, solitárias, pedunculadas, axilares, não emergindo de braquiblastos; pedúnculo 1,5-2,3 cm compr.; bráctea ausente; bractéolas ca. $1 \mathrm{~mm}$ compr., oblanceoladas, não estriadas, persistentes. Flores homomórficas, tetrâmeras, sésseis; cálice $0,5-1 \mathrm{~mm}$ compr., cupuliforme, não estriado, glabrescente, 4-denteado; corola 1,5-2 mm compr., campanulada, não estriada, rosada, glabrescente, lacínias ovais; estames 8 , filetes 5-8 $\mathrm{mm}$ compr., livres, róseos, anteras sem glândula apical; disco nectarífero ausente; ovário ca. $1 \mathrm{~mm}$ compr., subséssil, estilete 5-6 mm compr. Fruto não observado.

Material examinado: Candiba, Parque Estadual da Serra dos Montes Altos, despenhadeiro da estrada de Candiba, 21.II.2015, fl., E.C. Costa \& J.S. Nascimento 376 (HUNEB - Coleção Caetité).

Espécie endêmica do Brasil (Barneby 1991; Santos-Silva et al. 2015), onde é encontrada nos estados da Bahia, Goiás, Minas Gerais, Pernambuco e Piauí, crescendo em vegetação de Caatinga, Cerrado e Campo rupestre, entre altitudes de 320 a 1.200 m (BFG 2018). No PESMA foi encontrada em vegetação de Cerrado, em beira de estrada numa altitude de $625 \mathrm{~m}$. Flores foram observadas em fevereiro.

Mimosa gemmulata caracteriza-se por apresentar ramos inermes, foliólulos pequenos $(1,5-2$ $\times 0,5-1,2 \mathrm{~mm}$ ) com glândulas lentiformes sésseis na face abaxial, espigas cilíndricas e filetes róseos.

Ilustrações em Santos-Silva et al. (2015). 


\subsection{Mimosa hypoglauca Mart. var. hypoglauca} Flora 21(2, Beibl.): 53. 1838.

Figs. 5a-d; $7 \mathrm{~g}$

Subarbusto ca. $80 \mathrm{~cm}$ alt.; ramos cilíndricos, inermes, não estriados, não lenticelados, ferrugíneos, estrigosos, pubérulo-adpressos ou pubérulouncinados; braquiblasto ausente. Estípulas 3-5 mm compr., lanceoladas, não foliáceas, não ciliadas, não adnatas ao caule, caducas. Folhas bipinadas, 1 par de folíolos; pecíolo 4-6 mm compr., inerme, estrigoso, pubérulo-adpresso ou pubérulo-uncinado; nectário extrafloral ausente; espículas interpinais subuladas a lanceoladas; parafilídios triangulares; ráquila 2-6,7 cm compr.; foliólulos 21-32 pares, 5-9 × 1-2 mm, cartáceos, oblongos, base oblíqua,

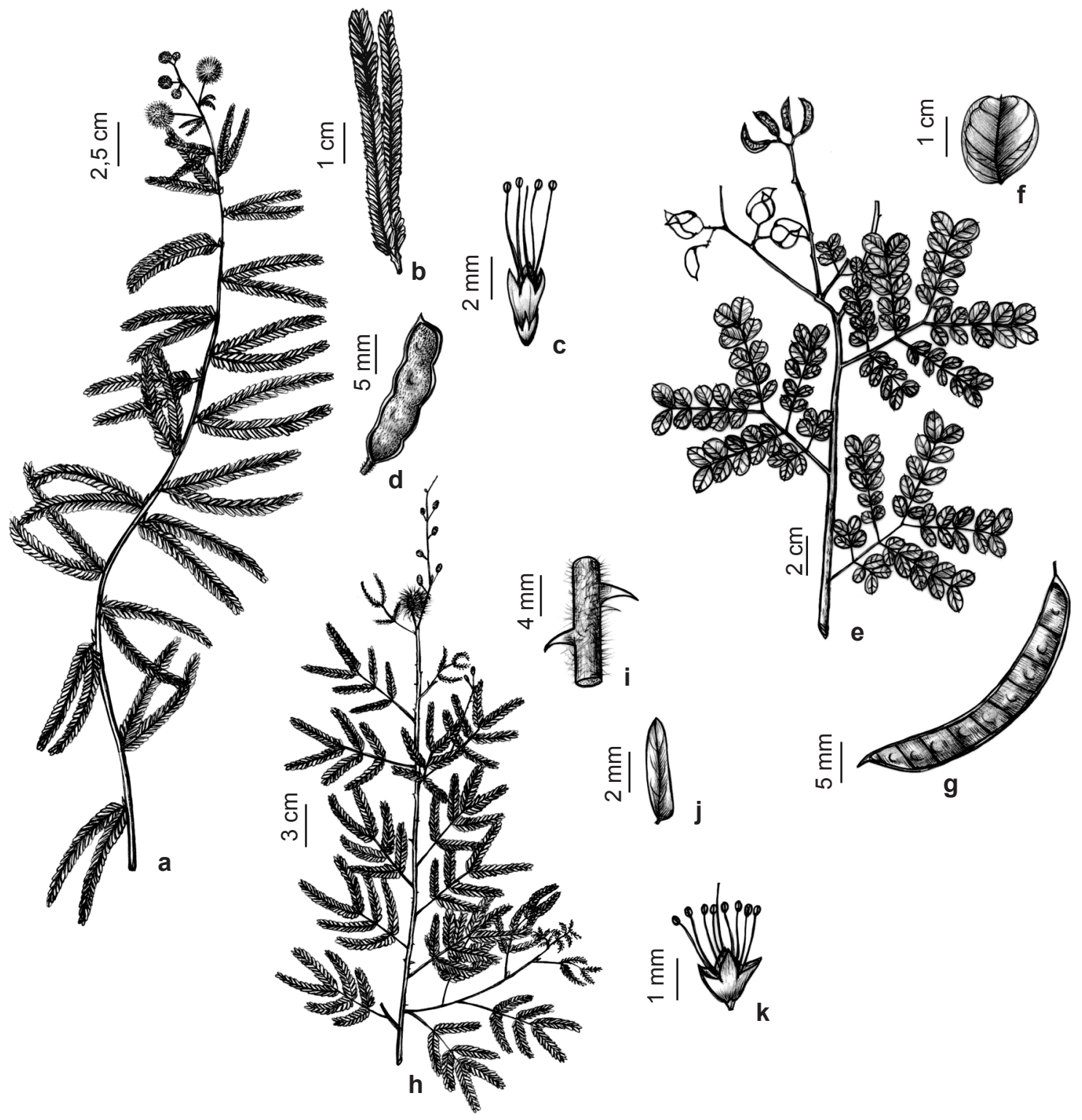

Figura 5 - a-d. Mimosa hypoglanga var. hypoglanca - a. ramo; b. folha; c. detalhe da flor; d. fruto. e-g. M. pithecolobioides - e. ramo; f. detalhe do folíolo; g. fruto. h-k. M. somnians - h. ramo; i. detalhe dos acúleos; j. detalhe do foliólulo; k. flor. (a-d J.M.S. Freire-Júnior 73; e-g J.M.S. Freire-Júnior 66; h-k J.M.S. Freire-Júnior76) Figure 5 - a-d. Mimosa hypoglauga var. hypoglauca - a. branch; b. leaf; c. detail of the flower; d. fruit. e-g. M. pithecolobioides - e. branch; f. detail of the leaflet; g. fruit. h-k. M. somnians - h. branch; i. detail of the aculeos; j. detail of the leaflet; k. flower. (a-d J.M.S. Freire-Júnior 73; e-g J.M.S. Freire-Júnior 66; h-k J.M.S. Freire-Júnior76) 
ápice obtuso ou mucronado, margem ciliada, seríceos, sem pontuação glandular; 3-4-nervados. Espigas globosas, homomórficas, solitárias ou 2-fasciculadas, pedunculadas, axilares ou reunidas em pseudoracemos terminais, não emergindo de braquiblastos; pedúnculo 3-3,5 cm compr.; bráctea ausente; bractéolas 2,7-3 mm compr., lanceoladas, não estriadas, persistentes. Flores homomórficas, tetrâmeras, sésseis; cálice 1,5-3 mm compr., tubuloso, não estriado, papiforme; corola 3-5 mm compr., infundibuliforme, pubérula, lacínias ovais, 1-nervadas; estames 4, filetes 0,8-1,5 cm compr., brevemente unidos na base, róseos, anteras sem glândula apical; disco nectarífero ausente; ovário ca. $1 \mathrm{~mm}$ compr., séssil, estilete $0,9-1,2 \mathrm{~cm}$ compr. Craspédios 1,8-2,8 × 0,5-0,6 cm, oblongos, sésseis, base atenuada, ápice agudo ou mucronado, cartáceos, verde oliva a castanhos, estrigosos. Sementes ca. $4 \times 3 \mathrm{~mm}$, orbiculares, sem arilo, não aladas, verde oliva escuro.

Material examinado: Candiba, Parque Estadual da Serra dos Montes Altos, 29.VI.2015, fl., J.M.S. Freire-Júnior 28 (HUNEB - Coleção Caetité); 28.X.2015, fl. e fr., J.M.S. Freire-Júnior 73 (HUNEB - Coleção Caetité). Sebastião Laranjeiras, Serra de Monte Alto, 8.IX.2006, fl., A.O. Soares Filho 12 (HUESBVC).

Espécie endêmica do Brasil (Barneby 1991). Ocorre nos estados da Bahia e Minas Gerais, em áreas de Cerrado e Campo rupestre, sobre solos arenosos, pedregosos ou sobre afloramento rochoso, em altitudes entre 700-1.350 m (BFG 2018). Encontrada no PESMA em ambientes de Cerrado e de Campo rupestre, sobre solos arenosos. Flores foram observadas em junho a outubro e frutos em outubro.

Devido principalmente ao tamanho das bractéolas e das espigas, ramificação dos ramos, número de foliólulos e divergências geográficas, Barneby (1991) reconheceu quatro variedades para M. hypoglauca (var. hypoglauca Mart., var. allostegia Barneby, var. dawsonii Barneby e var. syncollandra Barneby). Dessas, apenas as variedades hypoglauca e allostegia ocorrem no estado da Bahia, as demais estão restritas ao estado de Goiás.

Ramos ferrugíneos, folhas bifolioladas, flores tetrâmeras com cálice papiforme e filetes róseos, são as principais características para reconhecer Mimosa hypoglauca var. hypoglauca.

5.5. Mimosa ophthalmocentra Mart. ex Benth., Trans. Linn. Soc. Lodon 30: 415. 1875. Fig. 7h

Arbusto ca. 2,3 m alt.; ramos cilíndricos, aculeados, estriados, lenticelados, castanhos a acinzentados, pubérulos; tricomas tectores esbranquiçados; acúleos internodais, retos ou ligeiramente recurvados; braquiblasto ausente. Estípulas 2-7 mm compr., subuladas, não foliáceas, 3-nervadas, não ciliadas, não adnatas ao caule, persistentes. Folhas bipinadas, 2-5 pares de folíolos; pecíolo 0,5-1,5 cm compr., inerme, pubérulo; raque 10-27 mm compr., sulcada, inerme, não alada; nectário extrafloral ausente; espículas interpinais inconspícuas; parafilídios cônicos; ráquila 2-4 cm compr.; foliólulos 6-20 pares, 4-6 × 1,2-2 mm, cartáceos, oblongos, base obliquamente cordada, ápice agudo, margem não ciliada, glabros, sem pontuação glandular; nervação peninérvia. Espigas cilíndricas, homomórficas, solitárias ou 2-3-fasciculadas, pedunculadas, axilares ou agrupadas em pseudoracemos terminais, não emergindo de braquiblastos; pedúnculo 4-8 mm compr.; bráctea ausente; bractéolas 1-1,6 mm compr., lanceoladas, não estriadas, persistentes. Flores homomórficas, tetrâmeras, sésseis; cálice 0,7-1 mm compr., campanulado, não estriado, pubérulo, 4-denteado; corola 1,8-2,5 mm compr., infundibuliforme, não estriada, glabra, 4-angulada com nervuras proeminentes, esbranquiçada, lacínias encurvadas ou revolutas; estames 8 , filetes 4-6 mm compr., livres, brancos, anteras sem glândula apical; disco nectarífero ausente; ovário $0,5-0,8 \mathrm{~mm}$, séssil, estilete $3-5 \mathrm{~mm}$ compr. Craspédios 5-5,5 × 0,5-0,6 cm, oblongos, sésseis, plano-compressos, base atenuada a arredondada, ápice agudo a discretamente mucronado, cartáceocoriáceos, lustrosos, castanhos, glabros com tricomas glandulares sésseis. Sementes 4-7 × ca. $4 \mathrm{~mm}$, orbiculares, sem arilo, não aladas, marrons. Material examinado: Candiba, Parque Estadual da Serra dos Montes Altos, 27.VII.2015, fr., J.M.S. Freire-Júnior 48 (HUNEB - Coleção Caetité).

Material adicional: BRASIL. BAHIA: Rio do Antônio, Fazenda Mocó, 23.II.2008, fl., A.O. Soares Filho 9 (HUESBVC). Caetité, Aroeira Fazenda Hospício, 23.III.2010, fl., C.I.S. Lucas 56(HUNEB - Coleção Caetité).

É uma espécie característica da Caatinga, comum em diversos herbários do Nordeste (SantosSilva et al. 2015). Tem ocorrência confirmada nos estados da Bahia, Ceará, Paraíba, Pernambuco, Piauí, Rio Grande do Norte e Minas Gerais, em altitude que varia entre 300 a 600 m (Barneby 1991; Santos-Silva et al. 2015). Na área de estudo, foi encontrada em uma área desmatada e em regeneração de Cerrado sobre solo arenoso, com $1.154 \mathrm{~m}$ de altitude. Raramente é encontrada em área de Caatinga arbórea. 
Mimosa ophthalmocentra pode ser reconhecida na área de estudo pelos ramos aculeados, estípula 3-nervadas, folhas com 2 a 5 pares de folíolos, espigas cilíndricas, corola 4-angulada e pelos craspédios sésseis, castanhos.

Ilustrações em Santos-Silva et al. (2015)

5.6. Mimosa pithecolobioides Benth., Trans. Linn. Soc. London 30: 413. 1875.

Fig. 5e-g

Arbusto ca. 1,8 m alt.; ramos cilíndricos, inermes, estriados, não lenticelados, amarronzados, pubérulos; tricomas tectores esbranquiçados; braquiblasto ausente. Estípulas 2-3,5 mm compr., subuladas ou lanceoladas, não foliáceas, não ciliadas, não adnatas ao caule, persistentes. Folhas bipinadas, 2-3 pares de folíolos; pecíolo $0,5-1 \mathrm{~cm}$ compr., inerme, pubérulo; raque 1,2-3 cm compr., cilíndrica, inerme, não alada; nectários extraflorais entre os pares de folíolos proximais, crateriformes, sésseis, persistentes ou caducos; espículas interpinais triangulares; parafilídio ausente; ráquila $4-7 \mathrm{~cm}$ compr.; foliólulos 3-4 pares, 0,5-5 × 0,3-4,5 cm, cartáceos, largamente elípticos ou obovais, base oblíqua ou cordada, ápice arredondado ou mucronado, margem ciliada, face adaxial glabra a serícea, face abaxial serícea, sem pontuação glandular; nervação reticulódroma. Espigas cilíndricas, homomórficas, 2-3-fasciculadas, pedunculadas, axilares ou agrupadas em panículas terminais, não emergindo de braquiblastos; pedúnculo 1-3 cm compr.; brácteas 0,6-1,2 mm compr.; bractéolas $0,5-1 \mathrm{~mm}$ compr., lanceoladas, não estriadas, persistentes. Flores homomórficas, pentâmeras, sésseis a subsésseis; cálice $0,8-1,2 \mathrm{~mm}$ compr., campanulado, não estriado, pubérulo, lobos deltoides; corola 1,5-2 mm compr., campanulada, esbranquiçada, pubérula, lacínias deltoides, 1-nervadas; estames 10, filetes 3,5-5 mm compr., livres, amarelados, anteras sem glândula apical; disco nectarífero ausente; ovário 0,5-1 mm compr., subséssil, estilete 3,2-4 mm compr. Craspédios 3,3-5,5 × 1-1,5 cm, estreito-oblongos, sésseis, plano-compressos, base arredondada, ápice arredondado ou mucronado, glabrescentes, marrons. Sementes 4-5 × 3-3,5 mm, orbiculares, sem arilo, não aladas, marrons.

Material examinado: Palmas de Monte Alto, Serra de Monte Alto, 1.IX.2009, fl., A.O. Soares Filho s.n. (HUESBVC 5254). Candiba, Parque Estadual da Serra dos Montes Altos, 30.XI.2015, fr., J.M.S. Freire-Júnior 66 (HUNEB - Coleção Caetité).

Material adicional: BRASIL. BAHIA: Caetité, Brejinho das Ametistas, 22.V.2008, fl., M.L. Guedes \& F.S. Gomes 14432 (HUNEB - Coleção Caetité).
Espécie endêmica do Brasil, ocorrendo nos estados de Minas Gerais e Bahia, em vegetação de Caatinga, Campo Rupestre, Cerrado e Floresta Estacional Decidual (BFG 2018). Na Caatinga, geralmente $M$. pithecolobioides é encontrada em áreas de transição para Cerrado (Barneby, 1991). Essa espécie foi coletada no PESMA em área de Cerrado associado com Caatinga arbustiva-arbórea. Floresce em maio e em setembro, e frutifica em novembro.

Mimosa pithecolobioides é a única espécie de Mimosa do PESMA que possui nectários extraflorais entre os pares de folíolos proximais e flores pentâmeras em espigas. Pode ser reconhecida ainda pelas folhas amplas, com foliólulos largamente elípticos ou obovais.

5.7. Mimosa somnians Humb. \& Bonpl. ex Willd., Sp. PI. ed. 4: 1036. 1806.

Fig. 5h-k

Subarbusto ca. 1,8 $\mathrm{m}$ alt.; ramos cilíndricos, inermes ou aculeados, não estriados, não lenticelados, marrons, pubescentes; tricomas tectores e glandulares; acúleos intermodais, retos; braquiblasto ausente. Estípulas 4-6 mm compr., lanceoladas, não foliáceas, não ciliadas, não adnatas ao caule, persistentes. Folhas bipinadas, (1-)3-4 pares de folíolos; pecíolo $0,7-3 \mathrm{~cm}$ compr., inerme, pubescente, com tricomas glandulares ou não; raque $0,9-3 \mathrm{~cm}$ compr., sulcada, inerme, não alada; nectário extrafloral ausente; espículas interpinais lanceoladas; parafilídios cônicos ou subulados; ráquila $1,5-4,5 \mathrm{~cm}$ compr.; foliólulos 20-25 pares, $3,5-5 \times 1,5-1 \mathrm{~mm}$, cartáceos, oblongos, base obliqua, ápice obtuso, margem ciliada, face abaxial serícea, face adaxial glabra, sem pontuação glandular; nervação peninérvea. Espigas globosas, homomórficas, solitárias ou 2-fasciculadas, pedunculadas, axilares ou agrupadas em pseudoracemos terminais, não emergindo de braquiblastos; pedúnculo 1,5-2 cm compr.; bráctea ausente; bractéolas 2-2,2 mm compr., lanceoladas, não estriadas, persistentes. Flores homomórficas, tetrâmeras, sésseis; cálice 0,3-0,4 mm compr., campanulado, não estriado, glabro, 4-denteado; corola 2,1-3 mm compr., infundibuliforme, vinácea, glabra, lacínias ovais, 7-10-nervadas; estames 8, filetes 4-7 mm compr., brevemente unidos na base, róseos, anteras sem glândula apical; disco nectarífero ausente; ovário 0,7-1,2 mm compr., séssil, estilete 5-9 mm compr. Craspédios 4-5,5 × 0,3-0,4 cm, estreito-oblongos, estipitados, levemente plano-compressos, base cuneada, ápice mucronado, cartáceos, esverdeados, 

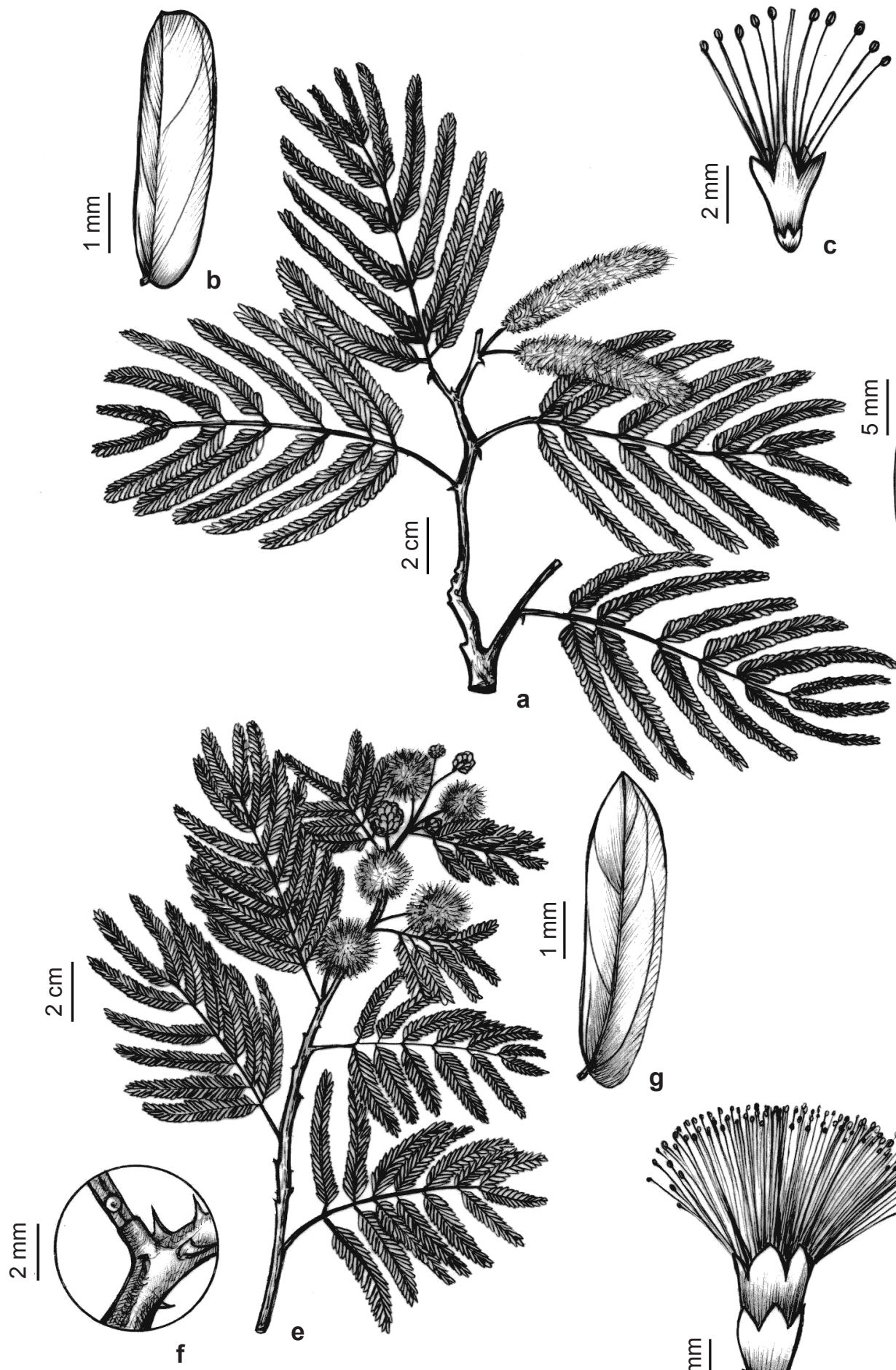

d
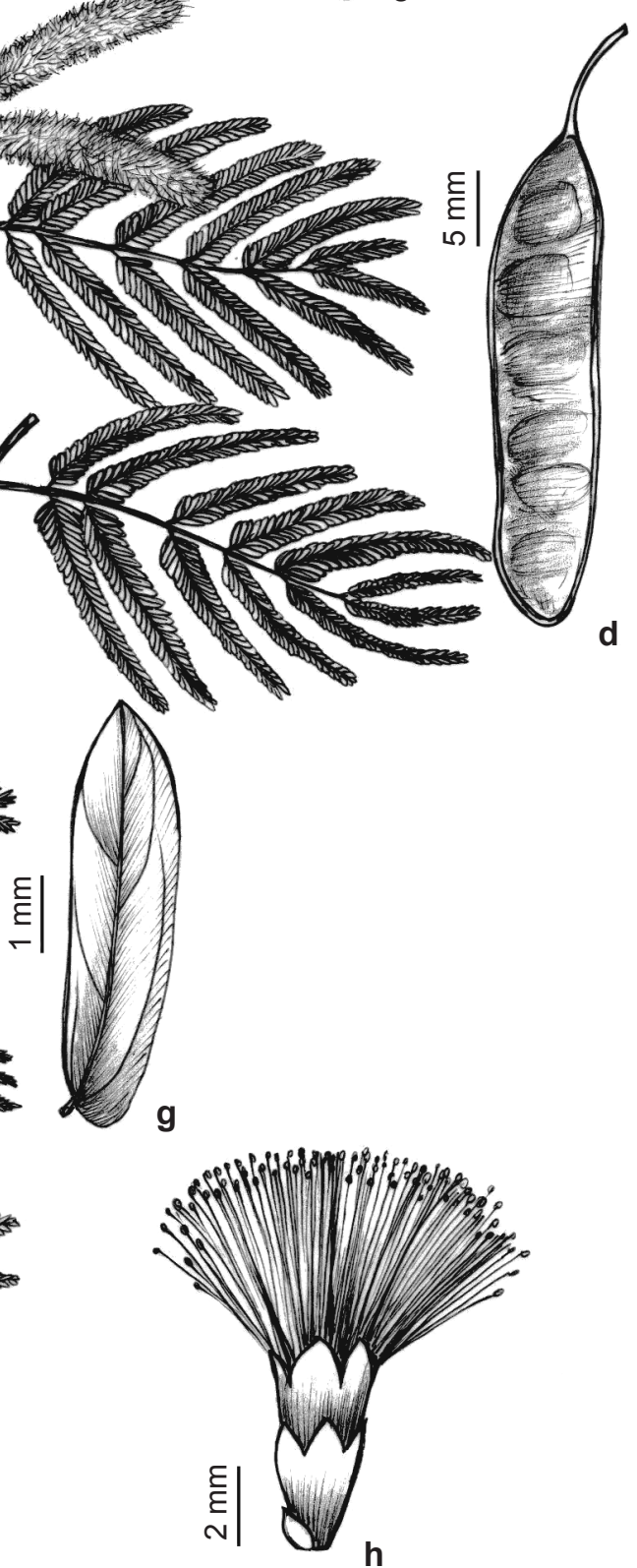

Figura 6 - a-d. Lachesiodendron viridiflorum - a. ramo; b. detalhe do foliólulos; c. flor; d. fruto. e-h. Senegalia polyphylla - e. ramo; f. detalhe dos acúleos e nectário extrafloral; g. detalhe do foliólulos; h. flor. (a-d J.M.S. FreireJúnior 70; e-h J.M.S. Freire-Júnior 91)

Figure 6 - a-d. Lachesiodendron viridiflorum - a. branch; b. detail of the leaflet; c. flower; d. fruit. e-h. Senegalia polyphylla - e. branch; f. detail of the aculeos and extrafloral nectary; g. detail of the leaflet; h. flower. (a-d J.M.S. Freire-Júnior 70; e-h J.M.S. Freire-Júnior 91 ) 


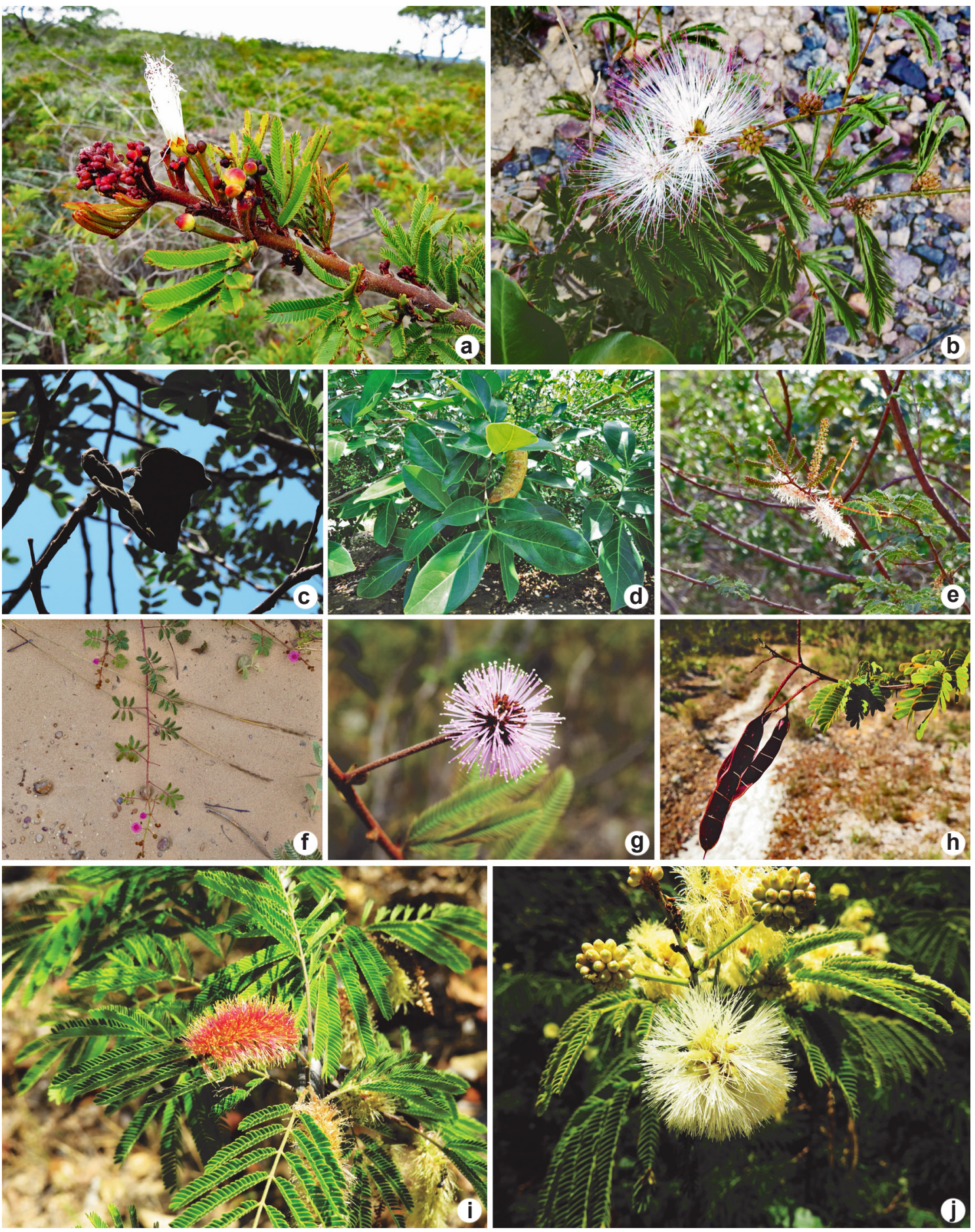

Figura 7 - Espécies do clado Mimosoide do Parque Estadual da Serra dos Montes Altos, Bahia, Brasil. a. Calliandra nebulosa; b. Calliandra sessilis; c. Enterolobium gummiferum; d. Inga laurina; e. Mimosa acutistipula; f. Mimosa campicola var. planipes; g. Mimosa hypoglauca var. hypoglauca; h. Mimosa ophthalmocentra; i. Lachesiodendron viridiflorum; j. Senegalia polyphylla. (Fotos: J.M.S. Freire Júnior)

Figure 7 - Species of Mimosoid Clade fom State Park of the Serra dos Montes Altos, Bahia, Brazil. a. Calliandra nebulosa; b. Calliandra sessilis; c. Enterolobium gummiferum; d. Inga laurina; e. Mimosa acutistipula; f. Mimosa campicola var. planipes; g. Mimosa hypoglauca var. hypoglauca; h. Mimosa ophthalmocentra; i. Lachesiodendron viridiflorum; j. Senegalia polyphylla. (Images: J.M.S. Freire Júnior) 
pubérulos. Sementes 2-3 × 1,5-3 mm, oblongas ou obovais, sem arilo, não aladas, castanho-escuras. Material examinado: Palmas de Monte Alto, Serra de Monte Alto, 25.I.2007, fl. e fr., A.O. Soares Filho 108 (HUESBVC). Candiba, Parque Estadual da Serra dos Montes Altos, 28.X.2015, fl., J.M. Freire-Júnior 76 (HUNEB - Coleção Caetité).

Material adicional: BRASIL. BAHIA: Caetité, Brejinho das Ametistas, 19.V.2009, fl., fr., M.S. Silva 24 (HUNEB - Coleção Caetité); MATO GROSSO DO SUL: Bela Vista: Alto Caracol km 569-570, beira de estrada, solo pedregoso, 11.III.2011, fl., J.S. Silva \& G. Shimizu 917 (HUENEB, Coleção Caetité).

Apresenta ampla distribuição na América tropical, ocorrendo do México à Argentina (Barneby 1991). No Brasil, Mimosa somnians pode ser encontrada em todas as regiões, onde cresce em Campo rupestre, Cerrado, Mata ciliar e de galeria, e em locais abertos e perturbados (BFG 2018). No PESMA foi encontrada em ambientes de Caatinga e de Cerrado em regeneração no entorno de uma nascente. Flores foram observadas em janeiro, março, maio e outubro. Fruto em janeiro e maio.

Mimosa somnians exibe uma grande variabilidade morfológica, provavelmente devido à sua ampla distribuição geográfica. Barneby (1991) reconheceu para esta espécie 10 variedades distribuídas em três subespécies. Porém a delimitação taxonômica destas variedades, baseadas na diferença no número e tamanho dos folíolos e foliólulos e no aspecto do indumento, é muito tênue. No presente estudo, optou-se por não considerar as variedades.

Apesar da ampla variabilidade morfológica, M. somnians pode ser reconhecida pelo hábito subarbustivo, com ramos revestidos por tricomas tectores e glandulares, espigas globosa, lacínias da corola 7-10-nervadas e filetes róseos.

\section{Pityrocarpa Britton \& Rose, N. Amer. Fl. 23(3):} 190. 1928.

Possui cerca de três espécies e distribuição nos trópicos da América do Sul e sul do México. Suas espécies ocorrem geralmente associadas às áreas secas (Jobson \& Luckow 2007). Apenas uma espécie foi encontrada no PESMA.

Pityrocarpa assemelha-se morfologicamente a Piptadenia e era até recentemente considerado como sinônimo deste gênero (Jobson \& Luckow 2007), mas difere principalmente por apresentar folíolos mais largos, romboides, oblongos a suborbiculares, fruto folículo com margens moniliformes, fortemente constritas entre as sementes.
6.1. Pityrocarpa moniliformis (Benth.) Luckow \& R.W. Jobson, Syst. Bot. 32(3): 573. 2007.

Árvore ca. $3 \mathrm{~m}$ alt.; ramos cilíndricos, inermes, não estriados, lenticelados, castanhos, glabrescentes; tricomas tectores esbranquiçados; braquiblasto ausente. Estípulas caducas. Folhas bipinadas, 1-3 pares de folíolos; pecíolo 1-3 cm compr., inerme, glabrescente; raque $2-6,3 \mathrm{~cm}$ compr., cilíndrica, inerme, não alada; nectários extraflorais no pecíolo, discóides a crateriformes, sésseis, persistentes; espícula interpinal ausente; parafilídio ausente; ráquila 4,5-8 cm compr.; foliólulos 7-10 pares, 1,1-1,7 ×0,7-1 cm, cartáceos, obliquamente oblongos, base assimetricamente arredondada a obtusa, ápice arredondado a obtusomucronado, margem não ciliada, pubescentes, sem pontuação glandular; nervação peninérveabroquidódroma. Espigas cilíndricas, homomórficas, solitárias ou 2-fasciculadas, pedunculadas, axilares, não emergindo de braquiblastos, pêndulas; pedúnculo 0,5-1,2 cm compr.; bráctea ausente; bractéolas 0,5-1 mm compr., triangulares, não estriadas, persistentes. Flores homomórficas, pentâmeras, sésseis a subsésseis; cálice $0,8-1 \mathrm{~mm}$ compr., campanulado, não estriado, pubescente, lobos agudos; corola 2-3 mm compr., campanulada, não estriada, amarelo-esverdeado, glabrescente, lacínias ovais; estames 10, heterodínamos, filetes 5-8 mm compr., livres, amarelos, anteras com glândula apical caduca; disco nectarífero ausente; ovário ca. $1 \mathrm{~mm}$ compr., estipitado, estípite 1,4-2 $\mathrm{mm}$ compr., estilete 3-6 mm compr. Folículos 5-6 $\times 0,8-0,9 \mathrm{~cm}$, moniliformes, com valvas constritas entre as sementes, estipitado, às vezes, espiralado longitudinalmente, base aguda a atenuada, ápice acuminado, cartáceos, castanhos, glabros. Sementes ca. $0,4 \times 0,5 \mathrm{~cm}$, orbiculares, sem arilo, não aladas, esverdeadas.

Material examinado: Palmas de Monte Alto, Serra de Monte Alto, estrada para o Brucunum, 26.I.2007, fl., O.A. Soares Filho \& R.C.S. Carvalho 134 (HUESBVC). Material examinado: BRASIL. BAHIA: Morro do Chapéu, estrada para a Iracê, 30.V. 2011, fr., L.P. de Matos 16 (HUEFS).

Espécie endêmica da região Nordeste do Brasil com ocorrência em vegetação de Caatinga, Carrasco e Floresta Estacional Semidecidual dos estados da Bahia, Piauí, Paraíba, Minas gerais e Rio Grande do Norte (BFG 2018). No PESMA foi encontrada em área de Caatinga arbórea. Floresce em janeiro.

Pityrocarpa moniliformis é uma espécie arbórea, podendo ser facilmente reconhecida 
pelos ramos inermes, inflorescências pêndulas e pelos filetes amarelos. Além disso, o fruto do tipo folículo, moniliforme regularmente constrito entre as sementes, às vezes, espiralado longitudinalmente, é uma característica marcante desta espécie.

Ilustrações em Queiroz (2009).

7. Pseudopiptadenia Rausch., Taxon 31(3): 559. 1982.

Gênero com 11 espécies e de distribuição neotropical (Lewis \& Lima 1991). No Brasil ocorrem nove espécies (Morim 2018), das quais uma espécie tem ocorrência confirmada no PESMA, em áreas de Florestas deciduais.

Gênero reconhecido pela presença de glândula apical nas anteras, fruto do tipo folículo ou criptolomento com sementes aladas.

\subsection{Pseudopiptadenia brenanii G.P.Lewis \&} M.P.Lima, Arch. Jard. Bot. Rio de Janeiro 30: 50 (1989-90 publ. 1991).

Árvore ca. $4 \mathrm{~m}$ alt.; ramos cilíndricos, inermes, não estriados, lenticelados, ferruginosos, quando jovens tomentosos, velutinos; tricomas tectores esbranquiçados; braquiblasto ausente. Estípulas 1-28 $\mathrm{mm}$ compr., triangulares a subuladas, não foliáceas, não ciliadas, adnatas ao caule, persistentes. Folhas bipinadas, 3-4 pares de folíolos; pecíolo 0,5-1,5 cm compr., inerme, pubérulo; raque 1,8-3 cm compr., cilíndrica, inerme, não alada; nectários extraflorais inserido próximo ao par de folíolos basais crateriformes, sésseis, persistentes; espícula interpinal ausente; parafilídio ausente; ráquila 4-5,5 cm compr.; foliólulos 9-16 pares, 4-6,8 × 2,5-4 mm, cartáceos, oblongos, base obliquamente truncada, ápice arredondado a agudo, margem ciliada, face adaxial pubescente, face abaxial glabra, sem pontuação glandular; nervação peninérvea, nervura mediana levemente oblíqua, proeminente. Espigas cilíndricas, homomórficas, solitárias, pedunculadas, axilares, não emergindo de braquiblastos; pedúnculo $0,6-1,5$ cm compr.; brácteas 1-1,2 mm compr.; bractéolas ca. 0,3 mm compr., lanceoladas, não estriadas, persistentes. Flores homomórficas, pentâmeras, sésseis a subsésseis; cálice $0,5-0,9 \mathrm{~mm}$ compr., campanulado, não estriado, glabrescente, lobos deltoides; corola 1,8-2,3 mm compr., campanulada, não estriada, verde-amarelada, glabra, lacínias lanceoladas; estames 10, filetes 3-4,4 mm compr., livres, amarelos a creme, anteras com glândula apical séssil; disco nectarífero ausente; ovário
0,8-1 mm compr., estipitado, estípite $0,3-0,5$ mm compr., estilete 3-3,5 mm compr. Folículos $7-12,5 \times 1,5-2 \mathrm{~cm}$, falcados, estipitados, planocompressos, com margens marcadamente sinuosas, irregularmente moniliformes, base arredondada, ápice cuspidado, verde-claro, velutinos. Sementes $1,3-1,5 \times 0,8-1 \mathrm{~cm}$, oblongas, sem arilo, aladas, verde-claro quando imaturas.

Material examinado: Sebastião Laranjeiras, Serra de Montes Altos, próximo à estrada para cachoeira do Brucunum, 14.I.2014, fl., A.O Soares Filho 29 (HUESBVC).

Material adicional: BRASIL. BAHIA: Caetité, Brejinho das Ametistas, caminho para o Bloco III, 22.V.2008, fr., M.L. Guedes \& F.S. Gomes 14435 (ALCB).

Espécie restrita aos estados de Minas Gerais e Bahia, onde ocorre em vegetação de Caatinga e Cerrado (BFG 2018; Morim 2018). No PESMA foi encontrada em Floresta Decidual crescendo em $935 \mathrm{~m}$ de altitude.

Pseudopiptadenia brenanii pode ser reconhecida pelo hábito arbóreo, ramos ferruginosos, velutinos, quando jovens tomentosos, foliólulos diminutos (4-6,8 × 2,5-4 mm), espigas axilares solitárias e frutos plano-compressos com margens sinuosas, velutinos.

Ilustrações em Queiroz (2009).

\section{Senegalia Raf., Sylva Tellur. 119. 1838.}

O gênero possui cerca de 210 espécies distribuídas nas regiões tropicais e subtropicais (Barros \& Morim 2014). No Brasil, são registradas cerca de 60 espécies encontradas nos domínios fitogeográficos da Amazônia, Caatinga, Cerrado, Mata Atlântica e Pantanal (BFG 2018). Na área de estudo foi registrada apenas uma espécie.

Caracteriza-se por apresentar hábito variado, folhas bipinadas, flores pentâmeras, polistêmones e fruto do tipo legume.

8.1. Senegalia polyphylla (DC.) Britton \& Rose, Ann. New York Acad. Sci. 35: 142. 1936.

Figs. 6e-h; $7 \mathrm{j}$

Árvore ca. 2,5 m alt.; ramos cilíndricos, aculeados, estriados, não lenticelados, marrons, glabrescentes; tricomas tectores esbranquiçados; acúleos internodais, retos ou ligeiramente curvados para cima; braquiblasto ausente. Estípulas 5-7 mm compr., lanceoladas, estriadas, não foliáceas, não ciliadas, não adnatas ao caule, persistentes. Folhas bipinadas, 6-9 pares de folíolos; pecíolo 2,5-3,7 $\mathrm{cm}$ compr., inerme, glabrescente; raque $5-10 \mathrm{~cm}$ compr., cilíndrica, inerme a esparso-aculeada, 
não alada; nectários extraflorais próximos à porção mediana do pecíolo, crateriformes, sésseis, persistentes; espícula interpinal ausente; parafilídios subulados; ráquila 4-8,5 cm compr.; foliólulos 24-35 pares, 0,9-1,4 × 0,3-0,4 cm, cartáceos, oblongo-lanceolados, base truncada, ápice agudo, margem ciliada, face adaxial glabrescente, face abaxial pubérula, sem pontuação glandular; nervação reticulódroma, nervuras proeminente na face abaxial, nervura principal excêntrica. Glomérulos hemisféricos, homomórficos, 2-5-fasciculados, pedunculados, agrupados em panículas ou pseudoracemos terminais, não emergindo de braquiblastos; pedúnculo 5-9 mm compr.; brácteas 0,5-1,2 mm compr.; bractéolas 0,5-1 mm compr., ovais, não estriadas, persistentes. Flores homomórficas, pentâmeras, sésseis; cálice 1,5-2 mm compr., campanulado, não estriado, pubérulo, lobos agudo; corola 3-4,3 mm compr., infundibuliforme, não estriada, branca, pubérula, lacínias ovais; estames numerosos, filetes 0,9-1,3 cm compr., livres, brancos a creme, anteras sem glândula apical; disco nectarífero ausente; ovário 0,5-1,4 mm compr., estipitado, estípite 2-3,2 mm compr., estilete 4-9,5 mm compr. Legumes 12-17 $\times 2-2,5 \mathrm{~cm}$, oblongos, estipitados, base aguda, ápice mucronado, coriáceos a lenhosos, castanhos, puberulentos. Sementes 1-1,2 × 0,7, ovóides, sem arilo, não aladas, marrons.

Material examinado: Sebastião Laranjeiras, Parque Estadual da Serra dos Montes Altos, 8.II.2016, fl., J.M.S. Freire-Júnior 91 (HUNEB - Coleção Caetité).

Material adicional: BRAZIL. BAHIA: Caetité, $7 \mathrm{~km}$ S de Caetité, 27.X.1993, fr., L.P. de Queiroz \& N.S. Nascimento 3613 (HUEFS).

Distribui-se desde o México até a Argentina (Queiroz 2009). No Brasil apresenta ampla distribuição, ocorrendo em todas as regiões em vegetação Cerrado, Floresta Estacional Semidecidual, Floresta Ciliar ou de Galeria, Floresta de Terra Firme e Floresta Ombrófila, (BFG 2018). No PESMA foi coletada em vegetação de Cerrado, crescendo na beira de estrada. Encontrada florida em fevereiro.

Senegalia polyphylla distingue-se pelos foliólulos relativamente largos (3-4 mm larg.) com a face adaxial glabrescente e face abaxial pubérula, nervação reticulódroma, glomérulos hemisféricos e filetes numerosos brancos a creme.

\section{Agradecimentos}

À Fundação de Amparo à Pesquisa do estado da Bahia - FAPESB, a concessão da bolsa de mestrado ao primeiro autor. À Universidade do Estado da Bahia, Departamento de Ciências Humanas, Campus VI, o apoio dado. Aos curadores dos Herbários HUEFS, HUNEB - Coleções Caetité e HUESBVC, a boa recepção durante as visitas e os empréstimos concedidos. A Regina Carvalho, as ilustrações.

\section{Referências}

Barneby RC (1991) Sensitivae Censitae. A description of the genus Mimosa L. (Mimosaceae) in the New World. Memories of the New York Botanical Garden 65: 1-835.

Barneby RC \& Grimes JW (1996) Silk tree, guanacaste, monkey's earring: a generic system for the synandrous Mimosoideae of the Americas. part. I. Abarema, Albizia, and allies. Memories of the New York Botanical Garden 74: 1-292.

Barneby RC (1998) Silky tree, guanacaste, monkey’s earring: a generic system for the synandrous Mimosaceae of the Americas. Memoirs of the New York Botanical Garden 74: 1-223.

Barros MJF \& Morim MP (2014) Senegalia (Leguminosae, Mimosoideae) from the Atlantic Domain, Brazil. Systematic Botany 39: 452-477

Barroso GM, Morim MP, Peixoto AL \& Ichaso CLF (1999) Frutos e sementes: morfologia aplicada à sistemática de dicotiledôneas. Editora UFV, Viçosa. $443 p$.

BFG - The Brazil Flora Group (2018) Brazilian Flora 2020: innovation and collaboration to meet Target 1 of the Global Strategy for Plant Conservation (GSPC). Rodriguésia 69: 1513-1527.

Cardoso DBOS \& Queiroz LP (2007) Diversidade de Leguminosae nas caatingas de Tucano, Bahia: implicações para a fitogeografia do Semiárido do Nordeste do Brasil. Rodriguésia 58: 379-391.

Córdula E, Queiroz LP \& Alves M (2008) Checklist da flora de Mirandiba, Pernambuco: Leguminosae. Rodriguésia 59: 597-602.

Dourado DAO, Souza AC \& Santos-Silva J (2013) O gênero Mimosa L. (Leguminosae: Mimosoideae) na APA Serra Branca/Raso da Catarina, Bahia, Brasil. Biota Neotropica 13: 225-240.

Ducke A (1953) As leguminosas de Pernambuco e Paraíba. Memórias do Instituto Oswaldo Cruz 51: 417-461.

Garcia FCP \& Fernandes JM (2015) Inga. In: Lista de Espécies da Flora do Brasil. Jardim Botânico do Rio de Janeiro. Disponível em: <http://floradobrasil.jbrj. gov.br/jabot/floradobrasil/FB23007>. Acesso em 28 fevereiro 2018.

Jobson RW \& Luckow M (2007) Phylogenetic study of the genus Piptadenia (Mimosoideae: Leguminosae) using plastid $t r n L-F$ and $t r n K / m a t K$ sequence data. Systematic Botany 32: 569-575. 
Lavin M, Schrire BP, Lewis G, Pennington RT, Delgado-Salinas A, Thulin M, Hughes CE, Matos AB \& Wojciechowski MF (2004) Metacommunity process rather than continental tectonic history better explains geographically structured phylogenies in legumes. Philosophical Transactions of The Royal Society B: Biological Sciences 359: 1509-1522.

Lewis GP (1987) Legumes of Bahia. Royal Botanic Gardens, Kew. 369p.

Lewis GP \& Lima MPM (1991) Pseudopiptadenia Rauschert no Brasil (Leguminosae-Mimosoideae). Arquivos do Jardim Botânico do Rio de Janeiro 30: 43-67.

Lewis GP, Schrire BD, Mackinder B \& Lock M (2005) Legumes of the world. Royal Botanic Gardens, Kew. 577p.

LPWG - Legume Phylogeny Working Group (2017) A new subfamily classification of the Leguminosae based on a taxonomically comprehensive phylogeny. Taxon: 66: 44-77.

Mori SA, Mattos-Silva LA, Lisboa G \& Coradin L (1985) Manual de manejo do Herbário Fanerogâmico. 2a ed. CEPLAC, Ilhéus. 103p.

Morim MP (2018) Pseudopiptadenia. In: Flora do Brasil 2020 em construção. Jardim Botânico do Rio de Janeiro. Disponível em <http://floradobrasil.jbrj. gov.br/reflora/floradobrasil/FB23130>. Acesso em 28 fevereiro 2018.

Mesquita AL, Morim MP \& Bonadeu F (2018) Enterolobium. In: Flora do Brasil $2020 \mathrm{em}$ construção. Jardim Botânico do Rio de Janeiro. Disponível em <http://floradobrasil.jbrj.gov.br/ reflora/floradobrasil/FB83156>. Acesso em 28 fevereiro 2018.

Moura ACA \& Barbosa MRV (1995) Lista de espécies da família Leguminosas na Caatinga Paraibana. Revista Nordestina de Biologia 10: 23-37.

Prado DE \& Gibbs EP (1993) Patterns of species distributions in the dry seasonal forests of South America. Annals Missouri Botany Garden 80: 902-927.

Pennington TD (1997) The genus Inga. Botany. Royal Botanical Garden. 844 p.
Queiroz LP (2009) Leguminosas da Caatinga. EUEFS, Feira de Santana. 441p.

Radford AE, Dickison WC, Massey R \& Bell CR (1974) Vascular plant systematics. Harper \& Row, New York. 891p.

Ribeiro PG, Luckow M, Lewis GP, Simon MF, Cardoso D, Souza ER, Silva APC, Jesus MC, Santos FAR, Azevedo V \& Queiroz LP (2018). Lachesiodendron, a new monospecific genus segregated from Piptadenia (Leguminosae:Caesalpinioideae: Mimosoid clade): Evidence from morphology and molecules. Taxon 67: 37-54.

Rodrigues CRM (2012) Um olhar sobre a Serra de Monte Alto: aspectos ambientais e de conservação. In: Silva JP (ed.) Territórios e ambientes da Serra de Monte Alto: região sudoeste da Bahia. Edições UESB, Vitória da Conquista. Pp. 25-51.

Santos-Silva J, Simon MF \& Tozzi AMGA (2015) Revisão Taxonômica das espécies Mimosa ser. Leiocarpae sensu lato (Leguminosae Mimosoideae). Rodriguésia 66: 95-154.

Silva JP (2012) Territórios e ambientes da Serra de Montes Altos: região sudoeste da Bahia. Edições UESB, Vitória da Conquista. 208p.

Simon MF, Grether R, Queiroz LP, Särkinen TE, Dutra VF \& Hughes CE (2011) The evolutionary history of Mimosa (Leguminosae): toward a phylogeny of the sensitive plants. American Journal of Botany 98: 1201-1221.

Souza ER (2015) Calliandra In: Lista de Espécies da Flora do Brasil. Jardim Botânico do Rio de Janeiro. Disponível em<http://floradobrasil.jbrj.gov.br/jabot/ floradobrasil/FB82724>. Acesso em 28 fevereiro 2018.

Soares Filho AO (2012) Fitogeografia e estrutura das florestas estacionais deciduais no Brasil. Tese de doutorado. Universidade Federal de Feira de Santana, Feira de Santana. 346 p.

Soares Filho AO, Harley AMG \& Souza AO (2012) Conservação do Parque e Refúgio da Serra dos Montes Altos. In: Silva JP (ed.) Territórios e ambientes da Serra de Monte Alto: região sudoeste da Bahia. Edições UESB, Vitória da Conquista. Pp. 195-208. 